\title{
WHERE DID ALL THE PAGANS GO? THE NON-CHRISTIAN SARCOPHAGI OF FOURTH-CENTURY ROME
}

\author{
by Robert Couzin*
}

\begin{abstract}
The number of Roman sarcophagi without explicit Christian iconography conventionally dated to the fourth century is not commensurate with any reasonable estimate of the number of well-to-do pagans. This article explores several possible explanations for the anomaly. One approach would be to attempt to correct the archaeological record by finding errors in the religious classification of monuments that exaggerate the Christian corpus, adding non-Christian sarcophagi that have escaped published inventories, or establishing a systematic misdating of pagan sarcophagi. Alternatively, the preserved monuments could be taken as an accurate reflection of original production, the shortfall implying some change in commemorative habits specific to nonChristians. The author concludes that neither of these theories is likely to reduce the pagan sarcophagus deficit substantially. Instead, the shortfall is ascribed mainly to differential rates of preservation. This hypothesis is consistent with certain medieval practices of reuse that suggest a higher probability of survival for antique sarcophagi bearing Christian imagery.
\end{abstract}

Il numero di sarcofagi romani senza un'esplicita iconografia cristiana convenzionalmente datati al IV secolo non è paragonabile a qualsiasi ragionevole stima del numero di pagani benestanti. Il presente articolo esplora diverse possibili spiegazioni per questa anomalia. Un approccio potrebbe essere quello di cercare di correggere il record archeologico, trovando errori nella 'classificazione religiosa' dei monumenti che esagera la stima del corpus cristiano, contemplando sarcofagi noncristiani che sono sfuggiti agli inventari pubblicati, o stabilendo un sistematico errore di datazione dei sarcofagi pagani. In alternativa, $i$ monumenti conservati potrebbero essere considerati come un riflesso accurato della produzione originale, implicando la mancanza di alcuni cambiamenti nelle abitudini commemorative specifiche dei non cristiani. Nel presente contributo si conclude che nessuna di queste teorie riesce comunque a ridurre in modo sostanziale la mancanza di sarcofagi pagani. Invece, il deficit può essere imputato principalmente ai differenti tassi di conservazione. Questa ipotesi è coerente anche con alcune pratiche medioevali di riuso, che paiono suggerire una maggiore probabilità di sopravvivenza per $i$ sarcofagi con repertorio figurativo cristiano.

Marble sarcophagi with figural relief carving were produced in Rome for over 300 years, from around AD 100 into the first decades of the fifth century. In the final phase, Christian imagery at first competed with and eventually displaced nonChristian themes. This transformation was a natural consequence of the growing number of Christians and their penetration into the ranks of the Roman elite and sub-elite who purchased such commemorative monuments. Having begun the fourth century as a minor and intermittently persecuted minority, the Christians ended it as a dominant majority. Pagans did not, 
however, disappear. ${ }^{1}$ They continued to serve in high public office, populate the legally established elite orders, and control considerable personal wealth. Yet, few sarcophagi conventionally dated to this period bear imagery that is not explicitly Christian.

The paucity of late pagan sarcophagi has often been remarked (Koch and Sichtermann, 1982: 259; Koch, 2000: 346-53; Wrede, 2001: 76-84), and the occasional enumerations, although not presented as exhaustive, refer to very modest numbers of such monuments. Andreae and Jung (1977) listed eighteen; twelve were noted by Koch and Sichtermann (1982: 259, n. 76). Jutta DreskenWeiland's more extensive, but still provisional, inventory (2003: 64-5, table 8) estimated that in the first three decades of the fourth century, 317 pagan sarcophagi were produced compared with 463 classified as Christian; for the period 330-400 she found only a further twelve non-Christian examples, against 325 Christian.

These numbers have not attracted the perplexity one might expect. Alan Cameron (2011a: 183-4), while defending the vibrancy of late Roman paganism, cited Dresken-Weiland's statistics without query or qualification. Hugo Brandenburg, on the other hand, wondered (2004: 14) 'that the number of neutral or pagan sarcophagi is surprisingly small having regard to the fact that Roman society, still solidly pagan for most of the 4th century, presumably needed a consistent supply of typical non-Christian sarcophagi'. Paul Veyne (2005: 784, n. 103) and Leonard V. Rutgers (2013: 513-14) also expressed surprise at the very few pagan sarcophagi ascribed to a period when there were still many pagans to occupy them. Several theories might be advanced in response to this conundrum. Before considering them, it is appropriate to summarize the demographic and material evidence for the phenomenon itself.

\section{THE PAGAN SARCOPHAGUS SHORTFALL}

Counting fourth-century Christians, pagans and their sarcophagi is not an exact science. The disparity between demography and the archaeological record can, however, be illustrated by contrasting estimates of the relevant populations with statistics from published sarcophagus catalogues, notably the Antiken Sarkophagreliefs (ASR) series and the three volumes of the Repertorium der christlich-antiken Sarkophage (Repertorium).

The demographic component of this comparison is illustrated in Chart 1 (generally following Couzin, 2014). It presents an estimate of the number of deaths among well-to-do Romans, those from households with sufficient disposable income to purchase an expensive marble sarcophagus, cumulated in

1 Notwithstanding its uncertain boundaries, origins in Christian polemic, antipathetic connotations and offence to twenty-first-century sensibilities, 'pagan' remains the preferred label for non-Christian (and non-Jewish) people and things in the Roman Empire. See North, 2005: 134-7; Cameron, 2011a: 14-31; Jones, 2014: 6-7. 


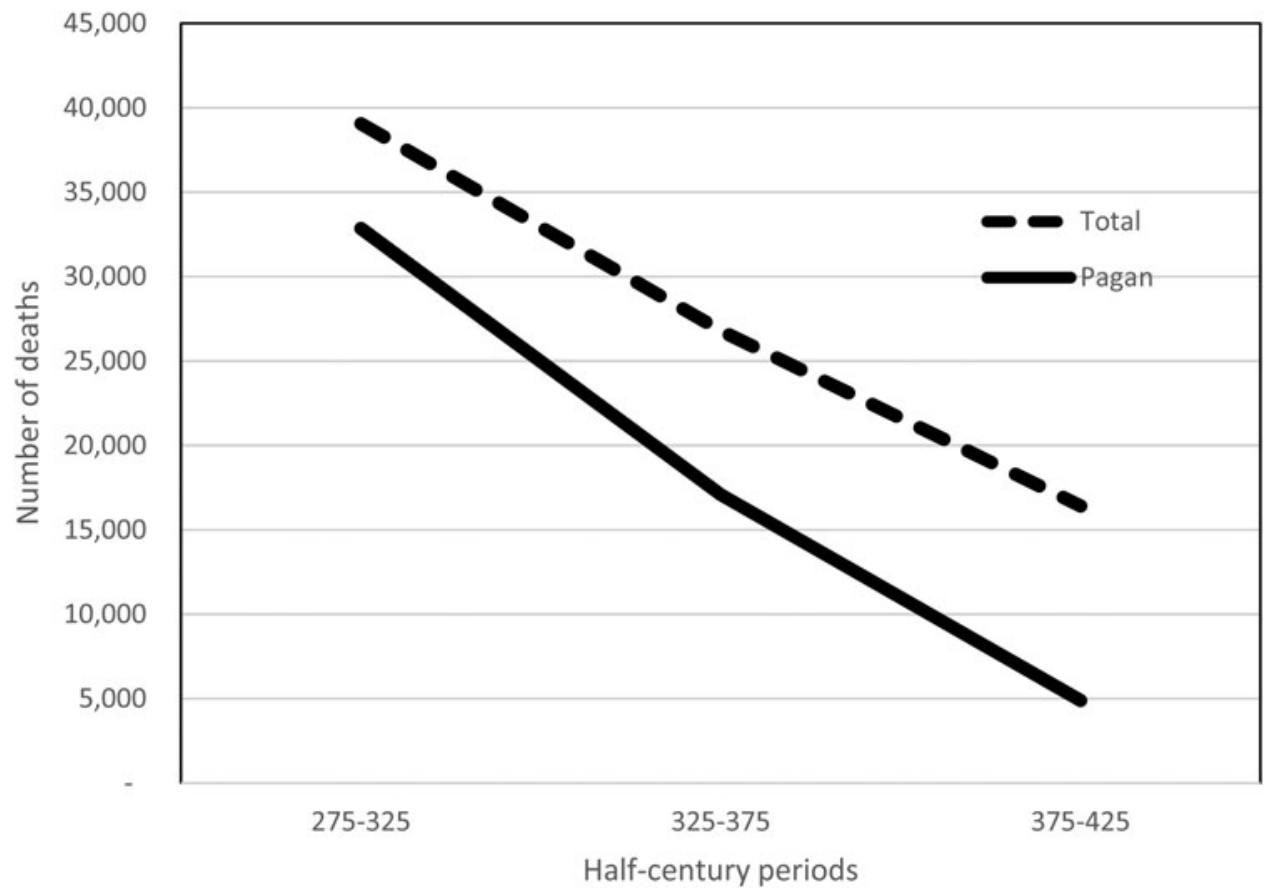

Chart 1. Deaths of well-to-do Romans.

half-centuries from AD 275 to 425. The top curve follows total deaths, and the lower curve deaths among the pagan contingent. (For a more detailed discussion of the data and analysis, with references, see the Appendix to this article.)

The negative slope of the top line on this chart reflects, first, a decline in the population of Rome during this period, by perhaps as much as a third. At the same time, economic factors conspired to accelerate the downward trend in the number of households able and willing to spend disposable income on funerary luxury. As per capita income fell, income inequality increased. Thus, there were fewer Romans, and the proportion of them living at or near subsistence, always a substantial majority in antiquity, rose. The rich became both richer and less numerous. The lower line falls even more steeply than the upper. This reflects the progressive Christianization (and consequential 'depaganization') of the Roman elite and sub-elite. The pace and timing of their conversion is uncertain and controversial, but not the overall result.

Consistent with this economic and religious demography, metropolitan sarcophagus production should have declined during the fourth century, and a decreasing proportion of the total should correspond to the demands of the traditional, non-Christian clientele. The archaeological record supports both these expectations, as illustrated in Chart 2.

The meaning and content of 'pagan' in this chart requires some clarification (for further detail on the underlying data, see the Appendix). Many late Roman 


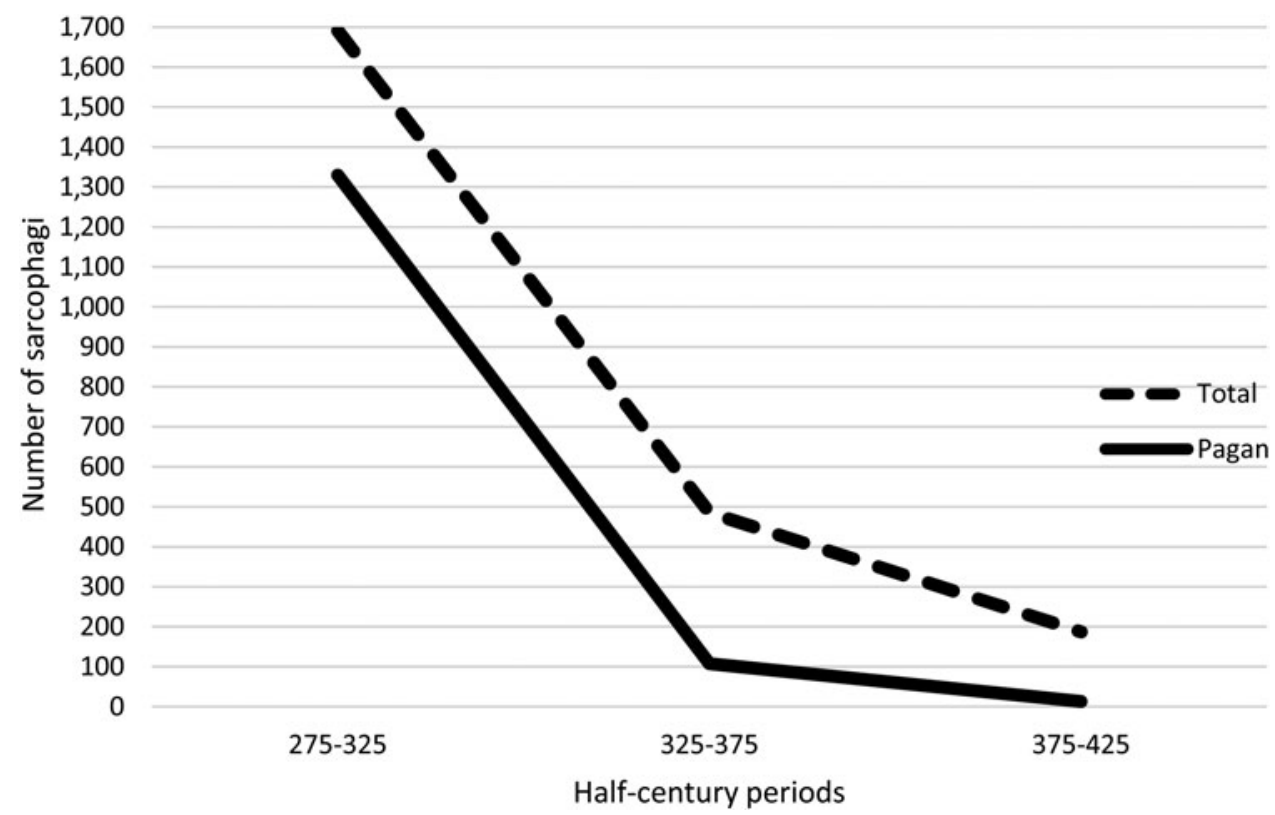

Chart 2. Preserved Roman metropolitan sarcophagi.

sarcophagi present no obvious indication of religious affiliation; which of these were originally occupied by Christians or non-Christians is unknown and unknowable. Potentially contentious examples range from ambiguous fragments (Fig. 1) to instances of shared or 'neutral' iconography like the common praying figures (orants) and bucolic motifs (Fig. 2). The enthusiasm of the pioneers of Christian archaeology to perceive Christian significance in such sarcophagi is apparent in Josef Wilpert's seminal catalogue (1929-32) and was only modestly tempered in the first volume of the Repertorium (Rep. I). A more rigorous delimitation of the Christian corpus, as already proposed by Klauser (1958-67), is reflected in the editorial policies of later Repertorium volumes (Rep. II and Rep. III). ${ }^{2}$ This more restrained approach was adopted by Guntram Koch (2000: 15-28), whose inventories were used to construct the data presented in Chart 2.

Koch's lists are mostly restricted to sarcophagi with Christian imagery: scenes from the New Testament and related apocrypha, doctrinal themes, or Old Testament motifs, these last almost always accompanied by more specifically Christian ones. The questionable fragments are omitted, as are most of the chests with neutral themes, even controversial pieces like the Three Shepherds sarcophagus in the Vatican Museums (Fig. 3). ${ }^{3}$

2 Compare the editorial policies in Rep. I: XIV (introduction by F.W. Deichmann), Rep. II: IX (foreword by J. Dresken-Weiland) and Rep. III: XVI (introduction by B. Christern-Briesenick). The more lenient approach is still occasionally promoted: see Provoost, 2004 and 2011.

3 Classed as Christian in Rep. I: no. 29; ASR V.4: 145, n. 934; Elsner, 2012: 183-4, n. 24; doubted by ASR V.2.2: 43; Koch, 2000: 17; Brandenburg, 2002: 32-3. 


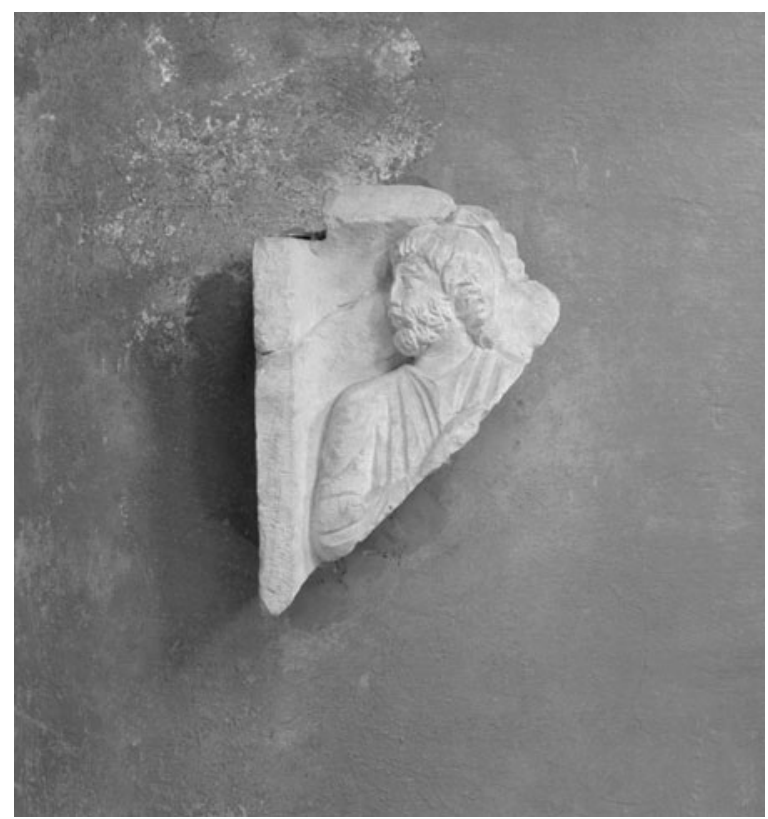

Fig. 1. Sarcophagus fragment. Cimitero di Pretestato, Rome. Photo: D-DAI-ROM 59.508 (J. Böhringer).

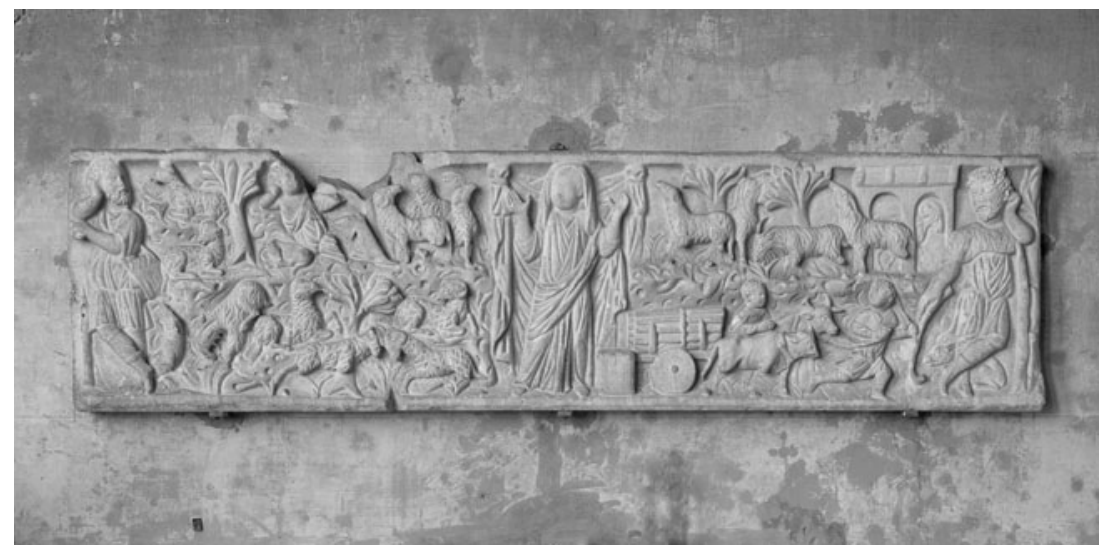

Fig. 2. Sarcophagus front with orans and bucolic motifs. Palazzo Farnese, Rome. Photo: D-DAI-ROM 64.1737 (Como).

These rigorous criteria could be still further tightened, but the refinements would have no material effect on the data. For example, a modest number of sarcophagi earn their Christian classification in Koch's inventory solely by their inscriptions. Some are secure - like the Christogram in Rep. I: no. 132 or the name of John the Evangelist in Rep. I: no. 784 - others rather less so. Grammatical variants of depositus, in particular, were not exclusively Christian; 


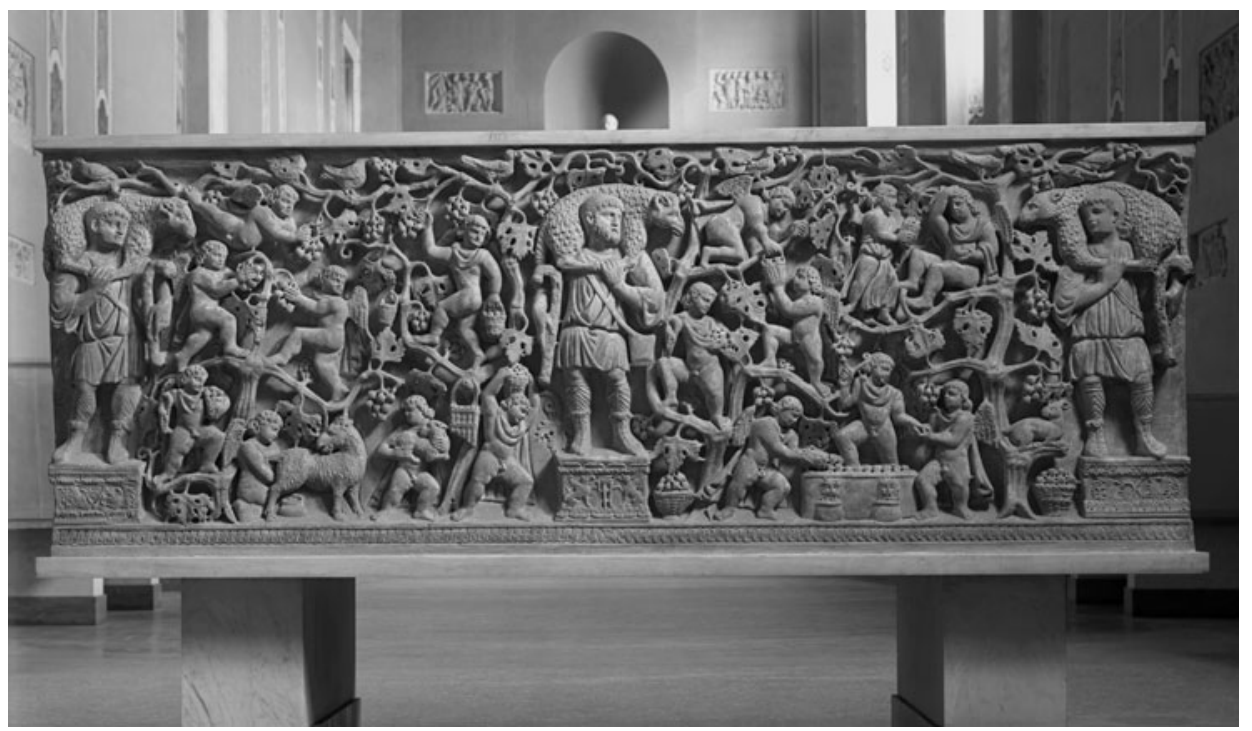

Fig. 3. Three Shepherds Sarcophagus. Museo Pio Cristiano, Vatican City, Inv. 181. Photo: D-DAI-ROM 3236.

the term was also used by pagans (Carletti, 2004) and occasionally by Jews (Kraemer, 1991: 159). It is also theoretically possible that additional pagan sarcophagi might lurk even amongst those with Christian imagery if common motifs achieved a certain secular or ecumenical status. Hijmans (2000) argued for just such a pagan appropriation of Jonah in a cubiculum vault mosaic. ${ }^{4}$ If crossovers of this nature did occur they were probably at least offset by the reverse phenomenon, the Christian use of sarcophagi with neutral decoration normally classed as pagan.

In the result, over half the Roman monuments in the Repertorium have been 'declassified'. To call them pagan, however, would merely substitute one questionable religious classification for another. Many of these sarcophagi, although bereft of explicit Christian decoration, were used by Christians. What are now illegible fragments could as easily have once been combined with a Christian as a non-Christian image; sarcophagi with neutral or classical decoration sometimes bear original or secondary inscriptions that demonstrate Christian use (Koch, 2000: 7-14; Rep. II: nos. 288-96). And even without such epigraphic evidence, it is reasonable to suppose, as most scholars do, that many did not baulk at adopting this sort of imagery which was, after all, often deployed alongside overtly Christian iconography.

The approach taken in constructing Chart 2 was to reallocate the sarcophagi catalogued as Christian but lacking Christian iconography. They were first placed within the half-century date ranges and then allocated between pagan

4 The hypothesized practice is rejected by Cameron (2011a: 183) and doubted by DreskenWeiland (2003: 65); but cf. Cantino Wataghin (2011) and Elsner (2003). 


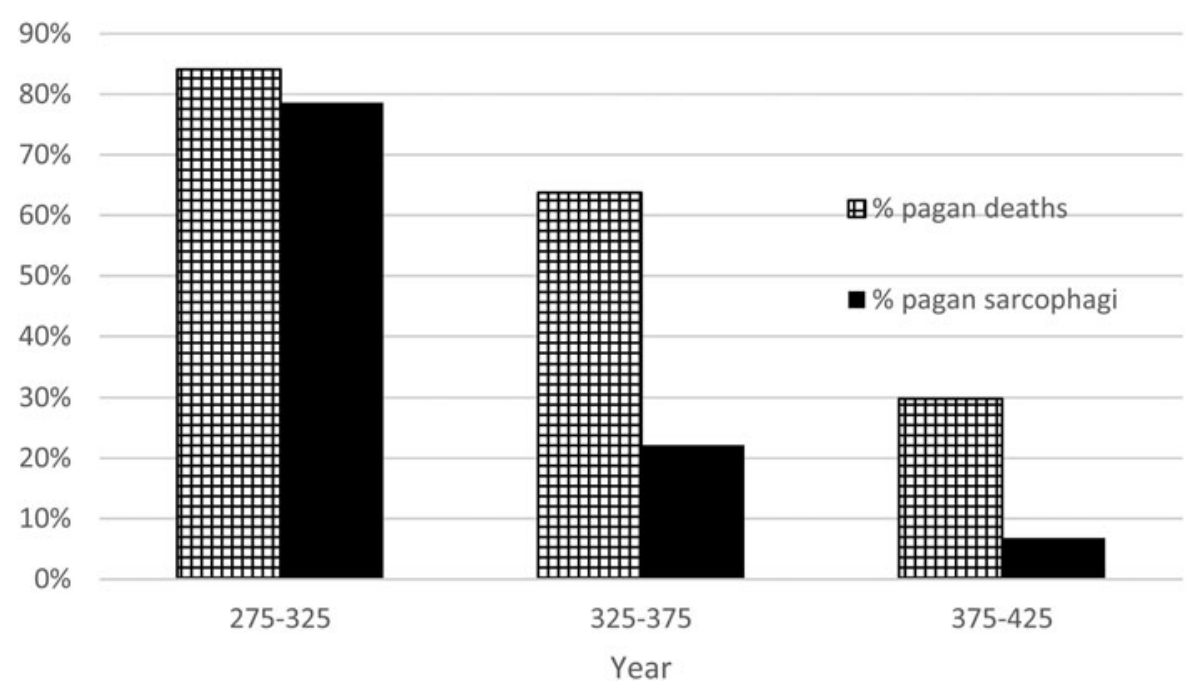

Chart 3. Deaths of well-to-do Romans and their sarcophagi.

and Christian applying the respective percentages otherwise determined, i.e., following the proportions established before this incremental expansion. The process (more fully explained in the Appendix) is generous to the pagans. Instead of the twelve late pagan sarcophagi cited by Dresken-Weiland, the Chart 2 data include 120. The goal of this exercise was not to resolve but rather to circumvent the thorny and ultimately insoluble problem of classification.

The evolution of populations and sarcophagi as represented in Charts 1 and 2 are directionally similar but the curves fall more steeply in Chart $2 .{ }^{5}$ The sharper plunge of its upper line reflects and illustrates the decline of the Roman sarcophagus habit and its ultimate disappearance early in the fifth century. The collapse of the bottom line, asymptotically approaching zero, points to a more rapid and totalizing Christianization of the monuments than of their potential occupants. Chart 3 represents this discrepancy more directly, recasting the data in the first two charts to compare pagan deaths with pagan sarcophagi.

These percentages should not be taken literally; the purpose here is not to measure the disparity between demography and the material record but merely to support its existence. Even at this coarse level of granularity, the dissonance is apparent, corroborating the sense in the literature that there are 'not enough' late pagan sarcophagi.

The bars in Chart 3 could be levelled either by lowering the percentage of pagan deaths or by raising the percentage of pagan sarcophagi. The demographic assumptions are certainly open to challenge; there is, in particular, no consensus regarding the rate of Christianization. The range of options,

5 The order-of-magnitude difference in the values on the vertical scales results mainly from the loss of the great majority of sarcophagi over the centuries. In addition, not all who had the wherewithal to choose this form of funerary commemoration did so. 
however, provides insufficient leeway to resolve the discrepancy. MacMullen (1984: 81) thought Rome still 'more pagan than Christian until the 390s'; such an estimate would considerably widen the sarcophagus gap. Stark (1996: 7) put the tipping point for the Empire as a whole closer to 350, which might slightly narrow it. Christian conversion in the upper income strata might have been a bit slower than assumed, but not likely much faster.

Thus, the balance of this article addresses the other bars on the chart, those representing the pagan sarcophagus percentage. Three categories of explanation will be considered. The first attempts to eliminate the disequilibrium by finetuning the archaeological record: searching for more pagan sarcophagi outside the catalogues or, following a conjecture proposed by Paul Veyne (on which, see below), revising the standard chronology. A second option is to accept the material record as accurately reflecting a precipitous decline in fourth-century production, presumably resulting from a shift in pagan mentalities. Neither erroneous interpretation of the record nor insufficient pagan production, however, provides an adequate explanation for the sarcophagus deficit. Instead, the imbalance between Christian and non-Christian monuments will be ascribed to a difference in survival rates, the result of a bias over the longue durée favouring the preservation of Christian imagery.

\section{CORRECTING THE RECORD}

Neither the accuracy nor the completeness of the archaeological record is entirely satisfactory. One way to close the fourth-century pagan sarcophagus gap would be to find more pagan sarcophagi. The most obvious source is within the large number dubiously classified as Christian, but that group has already been scoured in the construction of the data. Another place to look is outside the catalogues. Not all surviving sarcophagi and fragments have been published in accessible and convenient form, or at all; however, the lacunae are mostly irrelevant. Proposed or delayed additions to the ASR series, in particular, would mainly include sarcophagi that are either too early or extra-metropolitan. ${ }^{6}$ Of potentially greater concern are motifs that can escape publication, notably portraits and strigils.

Both are preserved in large numbers. The Arachne online database of the German Archaeological Institute and the Archaeological Institute of the University of Cologne includes 343 entries under the heading of portraits; 7 Stine Birk (2013) catalogues 677. Janet Huskinson estimates at around 800 the

6 On the evolution of the ASR project, see Elsner, 2011: 12; no volumes have been published since that time. There are also gaps on the Christian side, with proposed Repertorium 4 (Iberian Peninsula and Morocco) and 5 (Constantinople and the eastern Mediterranean): see https://www. dainst.org/projekt/-/project-display/113557.

7 http://arachne.uni-koeln.de/browser/index.php?view[layout]=sarkophag_set\&meta[search][search Meta][string]=Portrat. 
number of surviving strigillated sarcophagi (2015: 81). These portraits and strigils range from tiny bits to full monuments. The better preserved are generally included in either the ASR or the Repertorium (or both) by reason of the character of other motifs on the same object. Most of the rest have been assigned dates - on formal or stylistic grounds, or simply on the basis of probability - too early to be relevant to this study. ${ }^{8}$ More important, the uncatalogued fragments rarely provide any clear signal of religious affiliation; they could just as well have broken off from a Christian as from a nonChristian monument. It would be methodologically unsound to regard them as disproportionately pagan.

Another place to look for more fourth-century pagan sarcophagi, following a provocative suggestion by Paul Veyne (2005: 784, n. 103 and 782, n. 97), is in the large third-century corpus. Veyne's thesis is that the missing monuments are hiding in plain sight, mistakenly left out of consideration by virtue of erroneous dating. The conjecture is not extensively developed. It appears briefly in two footnotes with only one example to illustrate the thought, the Annona Sarcophagus conserved in the Museo Nazionale Romano, Rome (Fig. 4). ${ }^{9}$ Veyne challenges its customary date of $270-80$ on the basis that the deceased praefectus annonae (the official charged with the administration of the food supply of Rome) is depicted as a senator, an elevation in the status of this office that occurred only under Constantine. His hypothesis depends on the senatorial identification, which Veyne based on the appearance of a bearded figure standing behind the prefect in whom he recognized the Genius of the Senate. That interpretation, while not without scholarly support, does not represent the prevailing view. Reinsberg (ASR I.3: 124-5), after reviewing the opposing theories, concludes that the deceased was probably an equestrian, the order from which the praefectus annonae had traditionally been selected.

Finding more readily defended instances of mistaken dating is difficult. The Eutropos funerary plaque in Urbino might be cited as indirect evidence. It depicts a craftsman putting the finishing touches to a strigillated lenos sarcophagus with lions' heads (Fig. 5). ${ }^{10}$ The extant sarcophagi that most resemble the one pictured are generally dated towards the middle of the third century, occasionally into its fourth quarter, and almost never later. ${ }^{11}$ Yet, the plaque is often placed in the fourth century, generally on stylistic grounds. ${ }^{12}$ This could indicate that production of such lions'-head sarcophagi actually

8 On the uncertainty of dating strigils, however, see Koch and Sichtermann, 1982: 242; Huskinson, 2015: 27.

9 Inv. 40799; ASR I.3: no. 82, fig. 67.1; Koch and Sichtermann, 1982: 257, fig. 102. The iconography was originally deciphered by Paribeni (1909: 297-9).

10 Museo lapidario (Palazzo Ducale), inv. 40674. The plaque has a substantial bibliography. See, for example, G. Gori, 2007; Baratta, 2011 (with references in 31, n. 1).

11 Many comparable sarcophagi appear in ASR VI.1 and Baratta, 2008.

12 Gabrielli, 1961: 148; F. Gori, 2005; G. Gori, 2007; Baratta, 2011: 34; De Santis, 2013: 382-3. 


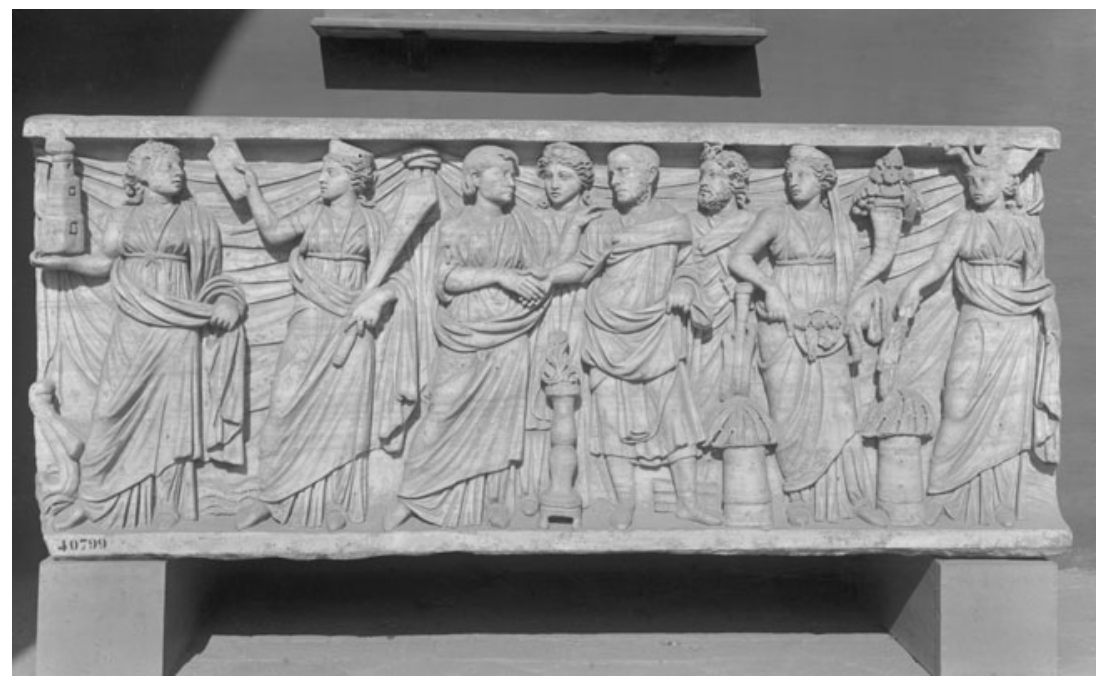

Fig. 4. Annona Sarcophagus. Museo Nazionale Romano, Rome, Inv. 40799. Photo: D-DAI-ROM 5459 (T. Weigand).

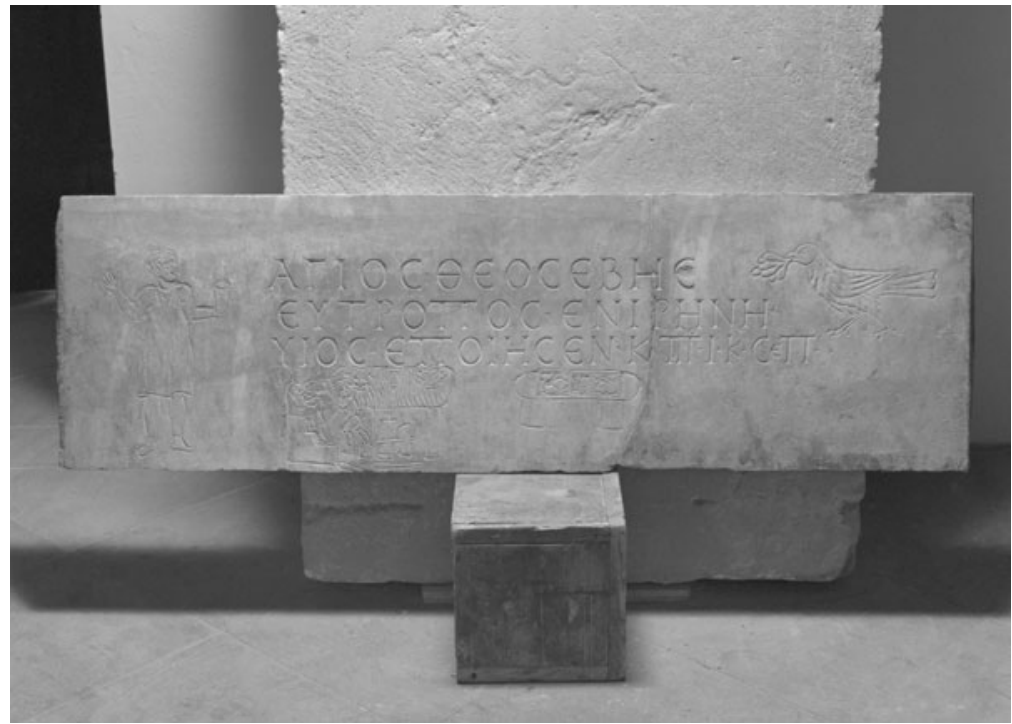

Fig. 5. Eutropos funerary plaque. Museo del Lapidario di Urbino, Inv. 40674. Photo: D-DAI-ROM 75.1101 (C. Rossa).

continued well after AD 300, but the more likely inference is that the grave slab is earlier, as several commentators have, indeed, proposed. ${ }^{13}$

13 Koch, 2000: 345 proposed c. 300; both Klauser, 1958-67, vol. 6 [1965-6]: 132, n. 15, referring to private correspondence with Antonio Ferrua, and Carletti, 2015, assigned it to the second half of the third century; De Rossi, 1877: 443 had opined it was not later than the third century; the earliest proposal, the 220s or 230s, is due to Bartman, 1993: 73, n. 51 with 72, n. 5. 
Notwithstanding the absence of reliable examples, redating is a tempting solution to the pagan sarcophagus deficit. Having regard to the secular decline in production through the fourth century and the large numbers of sarcophagi conventionally dated to the third, it is not necessary to assume that dating errors affect only one class of sarcophagi (pagan, not Christian) or point overwhelmingly in one temporal direction (forward, not back). A purely random chronological reallocation would increase the number of sarcophagi assigned to the later period with a far greater net gain in pagan than Christian numbers.

But this mathematical possibility cannot, in and by itself, warrant an overhaul of sarcophagus chronology. Although dating is imprecise and opinions regarding particular monuments are open to debate, a broad-brush and suspiciously teleological revision is unwarranted. It encounters, moreover, a stylistic obstacle. Earlier sarcophagi look different from later ones, and also from fourth-century public monuments like the Arch of Constantine whose influence on sarcophagi has often been remarked (L'Orange and Gerkan, 1939: 225; Stutzinger, 1982: 77-8). In theory, Roman workshops could have operated parallel production lines, supplying thousands of retro models to conservative pagan customers and 'modern' works to the Christians; in practice, artisanal, organizational and commercial considerations argue strongly against this notion.

\section{DEFENDING THE RECORD}

Instead of demanding an improbable correction, the material record of fourthcentury Roman sarcophagi could accurately reflect original production. In this case, the uneven bars in Chart 3 would indicate a much earlier abandonment of the sarcophagus habit by well-to-do pagans than by their Christian neighbours. The Christians of Rome also eventually gave up on sarcophagi in the first part of the fifth century. This later commemorative turn has been linked by some to an exogenous development - the socio-economic trauma following Alaric's sack of Rome in AD 410 (Stutzinger, 1982: 178; Koch, 2000: 223, 335, 339) - while others prefer to credit a growing Christian preference for burial ad sanctos, a change in mentality that prioritized location over display (Brandenburg, 2002: 22-3; Dresken-Weiland in Rep. II: XV). ${ }^{14}$ Shifting commemorative mentalities have also been invoked to explain the thirdcentury Entmythologisierung, a turn away from mythological themes in sarcophagus decoration (Zanker, 2005; Zanker and Ewald, 2012: 254-60; Koortbojian, 2013).

14 Conspicuous consumption and strategic positioning may, of course, coexist. Consider the monumental and elaborate sarcophagus of Junius Bassus (d.359; Rep. I: no. 680) deposited adjacent to the tomb of Saint Peter. 
These analogies have not been invoked with respect to the fourth-century pagan sarcophagus deficit, nor do they appear to be plausible. There is no evidence of socio-economic decline among the non-Christian elite or sub-elite of Rome and, in any event, such considerations have already been accounted for in the demographic data. That leaves the possibility of a shift in attitude, some newly discovered pagan funerary restraint. Yet, even as their dominance was challenged and eventually overthrown, pagans showed little evidence of fearful dissimulation.

Alan Cameron (2011b, 2016) sharply and convincingly joined issue with an interpretation of the literary sources by Stéphane Ratti, who imputed just such reticence to aristocratic fourth-century pagans (Ratti, 2010; 2012: 33-49). More directly relevant to commemorative display is evidence of an undiminished representational audacity. The commemoration in 384 of the death of the senator and consul designate Vettius Agorius Praetextatus is emblematic. His disappearance was mourned by crowds in the streets of Rome, perhaps dignified by a public funeral, and marked by the erection of several statues. These included the singular honours of a monument in the Roman Forum (LSA-1409; CIL VI 1779) and another consecrated by the Vestal Virgins, with whom he had served as pontifex (Kahlos, 2002: 151-9; Matthews, 2009: 131-2).

Such honorific statues are conspicuous testimony to continuing material display by elite pagans. At least half of the dozen or so erected in the Forum of Trajan in the fourth century represented non-Christian imperial officials, not counting emperors (Chenault, 2012: 130, table A). ${ }^{15}$ Far from being cautiously suppressed, pagan religious offices were proudly published on statue bases. The inscription for a statue of L. Aradius Valerius Proculus, dated 340, announced him to be augur, pontifex maior, quindecimvir sacris faciundis (LSA-1396; CIL VI 1690); serving Vesta and Sol are among the honours ascribed in 347 to Memmius Vitrasius Orfitus (LSA-1441; CIL VI 1739); a decade later Vulcacius Rufinus is qualified pontifex maior (LSA-1253; CIL VI 32051); towards the end of the century, Fabia Aconia Paulina, the widow of Vettius Praetextatus, is described beneath her statue as an initiate into the Eleusinian and other mystery cults, priestess of Hecate and devotee of Ceres (LSA-1474; CIL VI 1780). Statues were erected to honour at least two chief Vestal Virgins in the second half of the fourth century. ${ }^{16}$ Nothing suggests that pagans were more muted in their self-representation than their Christian peers.

A fortiori, pagan reticence would be surprising in the more modest gesture of funerary decoration. Sarcophagi were not on display for all to see. They were not paraded through the streets, even in the case of public rites associated with

15 Religious affiliation is based on formulae in inscriptions and prosopographic information. Most of the statues are in the LSA: 306, 314, 323, 342, 404, 1327, 1354, 1398, 1408, 2674, 2685 (1398 and 2685 are the same honorand).

16 LSA-1508, name erased, dated 364; LSA-2145, Coelia Concordia, dated 385. 
high-level aristocrats. Most sarcophagi were viewed only by family, household retainers and a few friends or associates. Epitaphs did not commonly include expressions of religious affiliation other than the ubiquitous DM (dis manibus), a formula not scrupulously avoided by Christians - Caldelli (1997) counted 158 examples - or even Jews (Kraemer 1991: 155-8). Most important, the preferred pagan funerary motifs in the fourth century comprised mostly secular or neutral themes, the deployment of which would not have attracted opprobrium, or even much notice.

Thus, apart from the dearth of sarcophagi itself, nothing points to a change in mentality regarding funerary display that would lead pagans to abandon the sarcophagus habit earlier than Christians. Short of such a revolution in pagan commemorative practices, an alternative - if novel and ultimately unconvincing - conjecture would attribute the decline in pagan sarcophagus production not to a renunciation of sarcophagal burial but rather to a greater inclination to reuse old chests.

Recycling marble was a long-standing Roman tradition, and reduced supply from eastern quarries in the third and fourth centuries sharpened the incentive (Fant, 2008: 132-3; Prusac, 2016: 16-19, 47-50, 118-22). Christian and pagan customers were equally likely to buy new sarcophagi made from reused marble, but the serial use of family funerary heirlooms or the acquisition of 'pre-owned' sarcophagi bearing mythological or other obviously pagan imagery could, hypothetically, have been more common in the non-Christian community. Like Veyne's redating conjecture, excess reuse of earlier sarcophagi by pagans would imply that the fourth-century shortfall can be made up from monuments already known and considered (in this case accurately) to have been produced in an earlier century. Also like the theory of chronological revision, disproportionate reuse is mathematically possible, theoretically tempting, and lacking empirical validation. It does not demand a complex organization of production to accommodate conflicting demands, but shares with the redating hypothesis an improbable divergence of taste between groups separated by religious affiliation and not much else.

\section{IGNORING THE RECORD}

The vast majority of sarcophagi are lost, destroyed, or altered beyond recognition. Those that survive are commonly considered to be indicative of what was produced. Inferences such as this are basic to archaeology and art history; sometimes, however, the record is misleading. Consider the material of antique sculpture. Literary and epigraphic sources confirm that the relative proportions of bronze and marble were far different in ancient cities than they are in modern collections (Stewart, 1990: 24-5; Daehner and Lapatin, 2015: 22). This particular discrepancy has a technical explanation; in other cases, social, cultural or political factors are responsible. For example, emperors who 
remained popular are over-represented in the corpus of surviving imperial portraits compared with those who were condemned by posterity (Varner, 2004).

The vicissitudes of survival also affect sarcophagi. Preservation and destruction were not uniformly practised or meted out. 'Unimportant' sarcophagi must have suffered the most, fields of strigillation and portraits of forgotten decedents attracting less benign attention in most periods than mythological themes, battles, hunts or biblical scenes. Given the subsequent religious and cultural history of Europe, one might anticipate another bias, this one tending to favour the conservation, or at least deter the erasure, of Christian as compared with non-Christian images. ${ }^{17}$

Hugo Brandenburg (2004: 14) briefly mooted the possibility that the 'hazards of preservation of late antique non-Christian sarcophagi' might be partly responsible for their rarity. Asymmetric rates of survival should not be invoked hastily to explain different frequencies among classes of artefacts. Ideally, any such hypothesis should be properly tested; however, in the case of Christian and pagan sarcophagi, a methodological conundrum arises: lost monuments cannot be examined, their original state is almost never documented and most of those that survive in legible condition are already included in the relevant catalogues. Nonetheless, there is persuasive, albeit indirect, evidence that supports the inference that sarcophagi with non-Christian decoration are less likely to have been preserved than otherwise similar monuments with Christian themes. In particular, certain practices in the medieval and occasionally in the later reuse of antique sarcophagi intimate a degree of differentiation based on iconography.

Antique marble sculptures, including sarcophagi, were recycled in lime kilns, used in the construction of walls and buildings, especially churches, and sometimes simply smashed to bits and discarded. ${ }^{18}$ Many remain undiscovered. The imagery on objects lost or subjected to destructive reuse can rarely be recuperated. Very occasionally, a preserved inscription or later description invites speculation regarding the appearance of a monument no longer extant. An eighteenth-century source claimed that a sarcophagus repurposed for an elite burial in 1440 in Santa Maria in Aracoeli, Rome, depicted 'figures of gladiators' (Casimiro Romano, 1736: 199); perhaps this was a battle scene (Agosti et al., 1984: 164). Such literary sources are, however, too few, equivocal and unreliable to inform a comparison of survival rates between pagan and Christian sarcophagi.

17 The focus here is the pagan sarcophagus deficit, but one might also speculate regarding the fate of Jewish sarcophagi. While religious compunctions, social status and economic wherewithal constricted the market for such monuments, the mere handful of surviving specimens may suggest a higher than average frequency of destruction. On Jewish sarcophagi in Rome, see Koch, 2002: 190-200. On the Jewish population, see Rutgers, 2006.

18 Greenhalgh, 1989, 2009; Settis, 2004; Kristensen and Stirling, 2016. This activity began early. C. Th. 9.17.2 and 9.17.4 (dated 349 and 357) prohibit taking marble from tombs for making lime or usage in construction. 
The scholarly literature on reuse concentrates instead on instances where the original sarcophagus imagery - however altered, damaged, supplemented or 'improved' - is still available for study. Hundreds of such recycled monuments have been discovered, and more are recorded in modern prints or drawings (Koch and Sichtermann, 1982: 627-32; Andreae and Settis, 1984; Huskinson, 2015: 271-5). The examples include Christian and non-Christian iconography, and occur from late antiquity to the present day. ${ }^{19}$ Reuse has attracted both conceptual and opportunistic theorizations: many patrons were motivated by antiquarianism, conspicuous consumption, or evocation of ancient family genealogy; all were attracted to the financial benefits of low-cost, high-quality marble. Reused sarcophagi with their ancient imagery still legible provide valuable raw material for the burgeoning field of spolia studies. ${ }^{20}$ But these have generally been catalogued. They do not, therefore, advance the cause of distinguishing between deficient production and impaired preservation as the primary cause of the fourth-century pagan sarcophagus shortfall.

There exists a tertium quid between destruction and preservation. Some sarcophagi were reused in a manner that concealed the iconography without eradicating it. This peculiar practice has been studied as an aspect of medieval attitudes towards Roman antiquities. ${ }^{21}$ It may also be relevant to the puzzle of the missing fourth-century pagan sarcophagi, because the known examples suggest that posterity was not entirely impartial in its treatment of Christian and non-Christian iconography.

Both types of imagery are often found on prominent display when sarcophagi have been incorporated into Christian tombs, embedded in church facades or, less respectfully, redeployed as planters or water troughs. But in the construction of a few sepulchral monuments the antique sarcophagus was reversed; its former back, conveniently left uncarved in common Roman practice, was then decorated to suit the new Christian occupant. A precocious, late-antique instance of this phenomenon is the reuse of a third-century Endymion sarcophagus for the burial of Saint Adeodatus, archpresbyter of Nola (d.473; Rep. II: no. 295; ASR XII.2: no. 78, fig. 76.1, 85.1-3; CIL X 1365). The mythological representation was turned away from the viewer who saw, instead, an epitaph extolling the virtues and ecclesiastical service of the holy man.

Such reversals occur repeatedly in the Middle Ages. The heirs of the Neapolitan noble Riccardo Piscicelli (d.1331) acquired a late-third-century Seasons

19 Examples: early Christian sarcophagi reused in the ninth (Rep. I: no. 340), tenth (Rep. I: no. 676), thirteenth (Rep. II: no. 123), sixteenth (Rep. II: no. 151) and eighteenth (Rep. II: no. 151) centuries; mythological and other pagan sarcophagi reused in the third (Rep. I: no. 929), eighth (Bejor, 1984: 93-4, fig. 1), twelfth (Gardner, 1992: 28, fig. 11), fourteenth (ASR I.3: no. 54, fig. 31.3; Huskinson, 2011: 61-4), fifteenth (Bejor, 1984: 96, fig. 6) and twentieth (Koch and Sichtermann, 1982: 632, fig. 182; Huskinson, 2015: 273, fig. 13.6) centuries.

20 Exemplified by Esch, 1969; Kinney, 1997; the contributions to Brilliant and Kinney 2011; and specifically focused on the material biographies of sarcophagi, Huskinson 2011.

21 Agosti et al., 1984; Cattalini, 1984: 219; Barbavara di Gravellona, 2002; Greenhalgh, 2009: 207-12. 

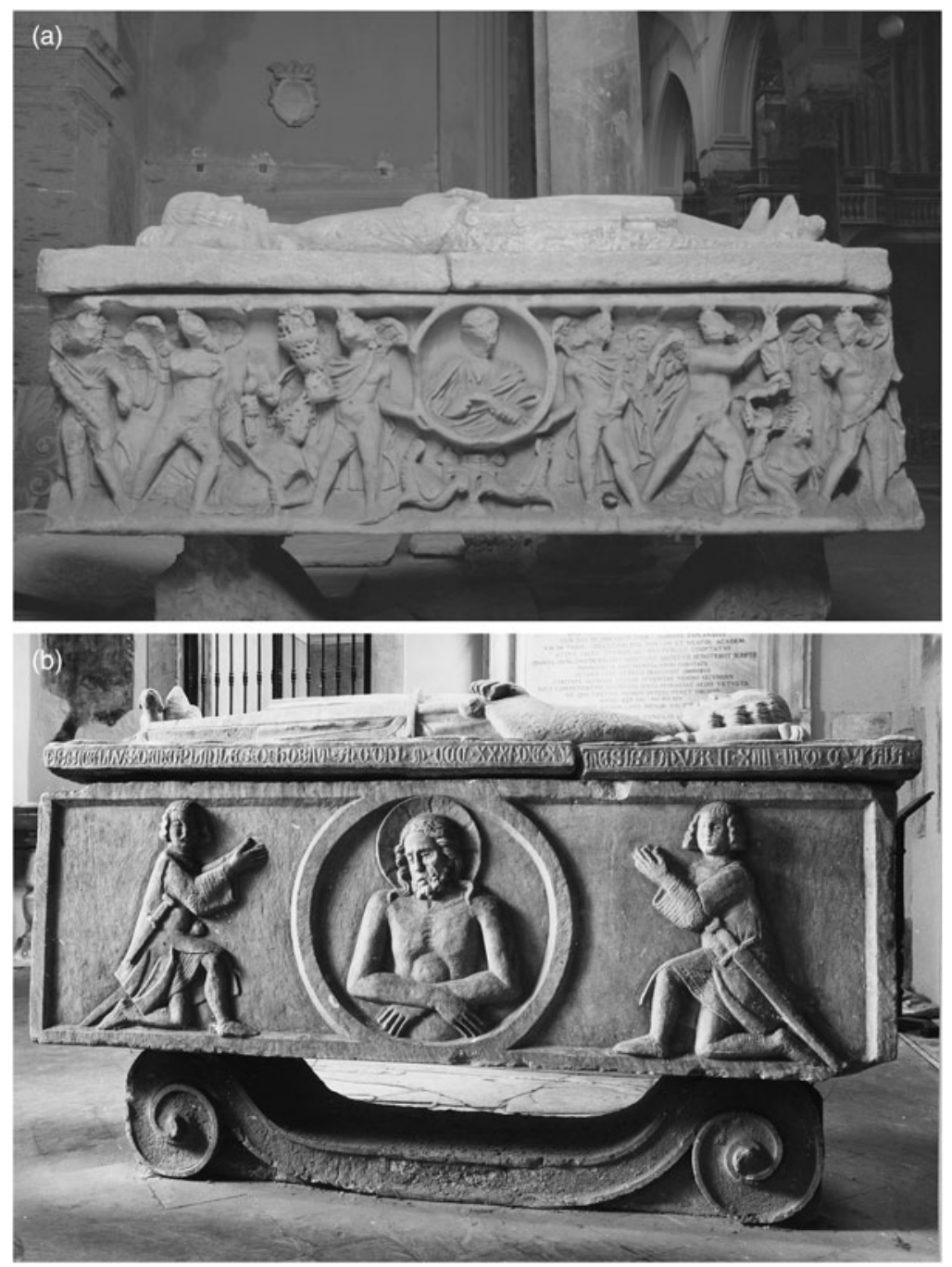

Fig. 6. (a) Piscicelli sarcophagus, antique face. Santa Restituta, Naples. Photo: D-DAI-ROM 66.1862 (H. Koppermann). (b) Piscicelli sarcophagus, medieval face. Santa Restituta, Naples. Photo: Conway Library, The Courtauld Institute of Art, London (A76/2220).

sarcophagus for his tomb in the family chapel (Fig. 6a) (Bridges and Ward Perkins, 1956: 168-9, fig. XXIII a, b; Barbavara di Gravellona, 2002: 204, figs 108-9; ASR V.4: no. 39, fig. 39.1). Its front was turned against the wall and a clipeus of the dead Christ between kneeling knights was carved on what used to be the back (Fig. 6b); heraldic arms were added to the short sides. The lid was also ancient, a strigillated sarcophagus front, now supplemented by a recumbent effigy of the deceased. The monumental tomb of Pope Clement IV (d.1268) in Viterbo incorporated a reoriented antique strigillated sarcophagus with the halfopen door motif, its rear face covered in the thirteenth century with an 
ostentatious Cosmatesque mosaic. ${ }^{22}$ Tritons, Nereids and an old inscription on a sarcophagus were put up against the wall of a Tuscan villa in the fourteenth century; the back was carved to present Christ in his tomb surrounded by the Virgin, Saint John the Evangelist, perhaps Nicodemus, and an archangel holding an olive branch. ${ }^{23}$

In another type of reversal, medieval tomb slabs were made from detached sarcophagus fronts flipped over to provide blank supports for new carving or incision. The extent of this practice is hard to judge, as most such monuments remain in situ in church pavements. Occasionally the old image is exposed when the floor is disturbed by accident or design. In the course of restoration work at Santa Sabina, Rome, early in the twentieth century, a slab commemorating the death of the Dominican Prior Ildebrandino da Chiusi (d.1309) and bearing his full-length image framed by a dedicatory inscription was dislodged. It was found to have been recuperated from a third-century strigillated sarcophagus with the spousal handshake motif. ${ }^{24}$

More than a dozen of these funerary sarcophagus reversals have been published. Most were performed in the thirteenth and fourteenth centuries. In addition to the Seasons, handshake and open-door motifs, they include mythological scenes, erotes, garlands and other pagan, classical or neutral designs, but no Christian themes. The only claimed exception is a dextrarum iunctio sarcophagus (Fig. 7a) that was turned around to create the tomb of Urban VI (d.1389) in the Vatican Grotto (Fig. 7b). Although qualified by some observers as early Christian, that attribution is doubtful. ${ }^{25}$ Its spousal handshake scene includes elements that are not found on any of the surviving Christian monuments that incorporate this iconography; the marriage god Hymenaeus with the couple and especially the standing corner figure on the left making a bloodless sacrifice securely declare the chest to have been originally made for a non-Christian customer, and there is no reason to suppose that the medieval patron and artisans would have failed to grasp the pagan character of such imagery. ${ }^{26}$

22 Luschi, 1984: 180-2, figs 6 and 15; Gardner, 1992: 55-6; Garms, Sommerlechner and Telesko, 1994: 206-15, figs 259-66; Barbavara di Gravellona, 2002: 205-8, figs 122-4. Antique sarcophagi with this motif were also reused without being turned around: Huskinson, 2015: 82, fig. 5.3.

23 Marcotti (1879: 145-8) reported the monument and opined that the pagan inscription is quite late, from the fourth or fifth century. Noted, with additional references, by Donati (1996: 117, n. 37).

24 Garms, Juffinger and Ward-Perkins, 1981: 279, no. LVII.4, fig. 21; Barbavara di Gravellona, 2002: 205, figs 118-20. The dextrarum iunctio on the reverse is ASR I.3: no. 119, fig. 25.5. Additional reversed grave slabs are noted by Garms, Juffinger and Ward-Perkins (1981: 46-7, no. II.3, and 83: no. XVII.1).

25 The early Christian claim is made by Agosti et al. (1984: 164; followed by Greenhalgh, 1989: 197) and repeated by Noè, 2000: 384. Gardner (1992: 125), Barbavara di Gravellona (2002: 205), Garms, Sommerlechner and Telesko (1994: 146-50) and Zalum (2000) either express no opinion on the matter or simply call the image 'antique'.

26 On the limited corpus of early Christian dextrarum iunctio sarcophagi and their iconography, see Bovini, 1946-8; Couzin, 2017: 30. 

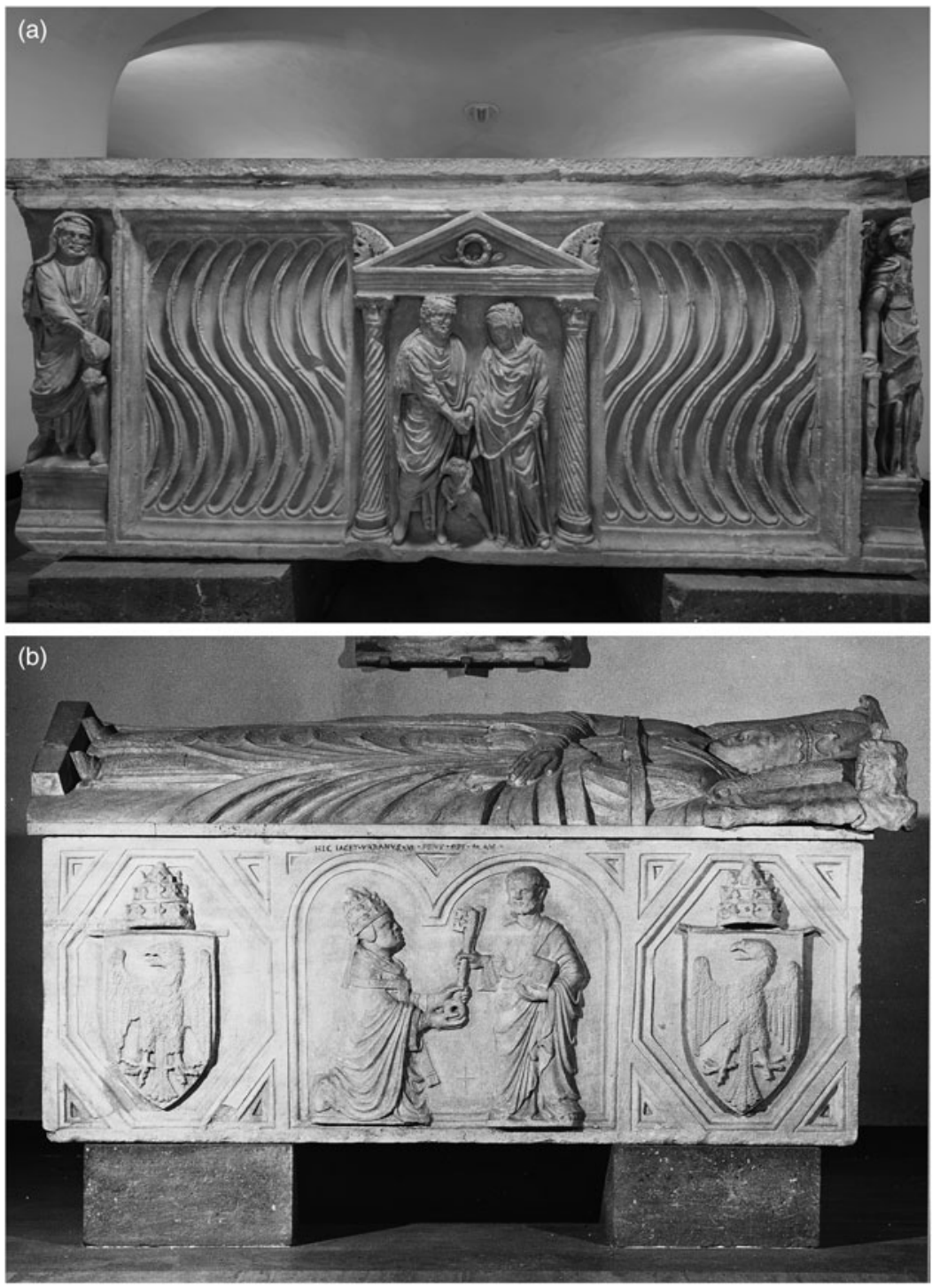

Fig. 7. (a) Sarcophagus of Urban VI, antique face. Saint Peter's, Vatican City. Photo: M. Falcioni, with kind permission of the Fabbrica di San Pietro in Vaticano. (b) Sarcophagus of Urban VI, medieval face. Saint Peter's, Vatican City. Photo: Conway Library, The Courtauld Institute of Art, London (A73/3137, by James Austin).

The discreet placement of classical imagery out of the viewer's sight in the construction of these commemorative monuments could have signalled a pious antipathy to paganism, but the primary rationale was probably practical, all the more so in the many instances where the disguised imagery is anodyne. Reversing a sarcophagus or turning over its front face was an efficient way to reuse expensive marble while making space for Christian religious affirmation, self-representation or contemporary forms of luxurious exhibition. Whatever 
the rationale, there appear to be no analogous examples of concealing early Christian relief carving.

Another camouflage technique is recarving. Artisans sometimes erased and replaced the image in a portrait clipeus, in the central mandorla of a strigillated design or in an inter-columnar space. Since sculpture in stone is a subtractive process, this usually left insufficient material for extensive new relief carving. The reclaimed blank surface could, however, be refilled with a flat motif like a cross or heraldic arms. ${ }^{27}$ One cannot reconstruct imagery that has been obliterated, but the inference that it was not likely to have been explicitly Christian is sometimes confirmed by other subsisting elements of the original programme.

Thus, Seasons still stand at the corners of a late third- or early fourth-century sarcophagus in Sardinia, the central panel of which presents only an austere, flat Latin cross (Fig. 8; ASR V.4, 231: no. 190, fig. 75.5; Porcu Gaias, 1996: 12, cat. 3). Pesce (1957: 97-8, no. 55, figs 105-6) thought the cross was original, and many Christian sarcophagi do have a cross in a central field. Most of these are not metropolitan (e.g. Rep. II: 312-59, 407, 408), although there are also Roman examples (e.g. Rep. I: 243, 687, 856). In every case, however, the arms of the cross are flared at the ends and quite unlike the stark form of the one in Sardinia, which seems to be an early modern substitution, similar to another sarcophagus in Milan with consular figures preserved at the corners and a flat, simple cross in the centre (Rep. II: 292). ${ }^{28}$ Such a cross could have replaced a standing figure of the deceased, but the erased and refilled field might also have borne pagan imagery, like the Three Graces on a comparable sarcophagus formerly in Hever Castle, England. ${ }^{29}$

Even when all that remains of the carving are architectonic forms, it may be possible to make an informed inference regarding the original imagery. On a reused monument in Pisa, the only preserved antique elements are columns, capitals and connecting arches; whatever appeared under the arcade was entirely replaced in the fourteenth century by four shields bearing the arms of the Rustichelli family and two crosses (Arias, Cristiani and Gabba, 1977: 111, A 20 int., figs 108, 109). The even number of bays, however, strongly implies that the imagery was not Christian. While arrangements with four or six niches may not be especially common on pagan sarcophagi, they are entirely foreign

27 Examples: Rep. II: no. 288 (= ASR VIII.2: no. B 21), 290, 291 (=ASR VIII.2: no. A 39 / B 20) (crosses in niches); Arias, Cristiani and Gabba, 1977: 61-2, A 10 est., figs 19-21 (arms in the mandorla of a strigillated lions'-head lenos sarcophagus) and 107-8, A 15 int., fig. 102 (arms in clipeus).

28 The ASR notice calls the cross on the sarcophagus in Sardinia 'modern'; Porcu Gaias considers it a later addition, without suggesting a date. The Repertorium notice regarding the Milan sarcophagus classes it as pagan and also regards the cross as a subsequent alteration.

29 Compare ASR V.4: 231, no. 191, fig. 75.4 (standing figure) and ASR V.4: no. 146, fig. 67.2= ASR XII.2: no. 160, fig. 125.2 (the Three Graces). 


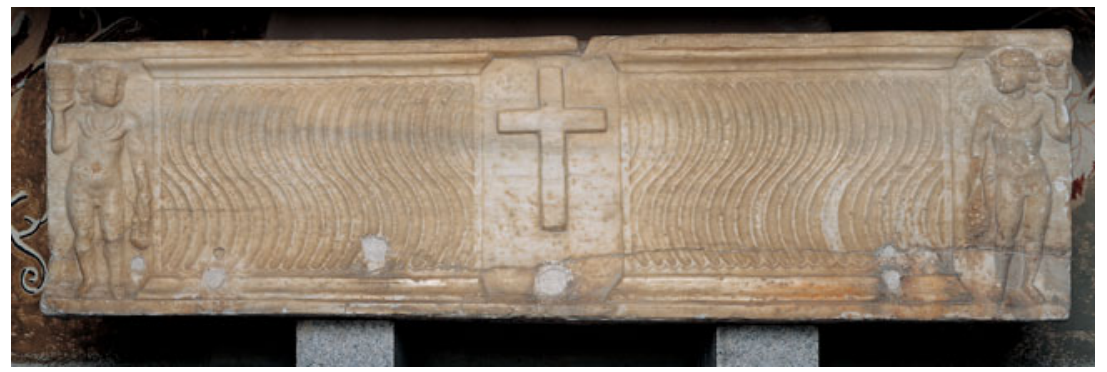

Fig. 8. Strigillated sarcophagus front. Chiesa di San Francesco dei Cappuccini, Sassari, Sardinia. Photo: Porcu Gaias 1996: 12, cat. 3, (C) Archivio Ilisso Edizioni.

to the Christian corpus. ${ }^{30}$ Only a single instance appears in the Repertorium and it is an obvious emulation of a pagan prototype; the Christian imagery appears only on the short sides. ${ }^{31}$

The actual revision, rather than simple elimination, of images was largely limited to portraits (Prusac, 2016: 18, 79-92, 121). The mere substitution of new self-representations for old had no particular religious resonance; however, recarving could also operate to Christianize a pagan sarcophagus, just as Roman statues were transmuted into Christian saints (examples in Wiegartz, 2004: 147-51). The original clipeus busts on two sarcophagi in Pisa were refashioned early in the thirteenth century into a bearded, nimbed, blessing Christ (Fig. 9) and a veiled, cross-armed Virgin, thereby rendering the antique vessels suitable repositories for the relics of the local holy figures Beato Domenico Vernagalli and Santa Bona. Both strigillated sarcophagi are likely pagan antiquities, the former more securely so given the satyrs still dancing at its corners. ${ }^{32}$

The recarving examples do not provide extensive information concerning later attitudes towards Christian and pagan sarcophagus imagery. Both sorts were reworked to repair damage and alter portraits, and neither underwent extensive lapidary surgery to remodel or replace the iconography. Yet, it is significant that the erasure of imagery seems to have been limited to, or at least concentrated within, the pagan group, while any new assertion of a religious denomination was, of course, always Christian.

30 On the even number format in the non-Christian context, see Koch and Sichtermann, 1982: 77-8, 148-9, fig. 168 (Hercules); ASR V.4: no. 7 (Seasons); ASR I.3: no. 87, 123, 140 (dextrarum iunctio with Dioscuri).

31 The unique Christian example, based on the Roman four-bay spousal handshake models, is Rep. III: no. $51=A S R$ I.3: no. 3. A six-bay Christian sarcophagus in Warsaw is not late antique but modern, a reordered and reduced version of a five-bay chest in Ravenna: ASR VIII.2: 124 n. 519, fig. 92.2; Rep. II: 144 and no. 381.

32 Arias, Cristiani and Gabba, 1977: 102-3, A 9 int., figs 88-90, 104-5, and A 11 int., figs 94-5. Donati (1996: 108-9) called the satyrs 'erotes', but compare similar figures on ASR IV.4: nos. 284, 295, 296 and especially 313. 


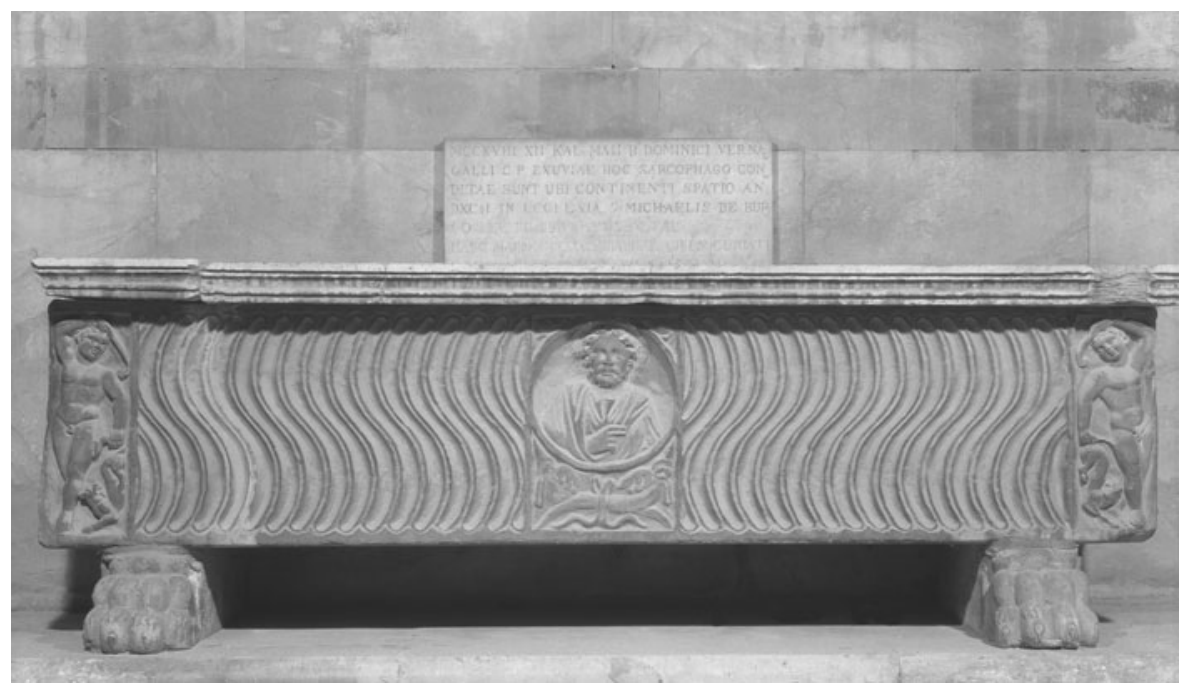

Fig. 9. Sarcophagus front. Camposanto, Pisa. Photo: D-DAI-ROM 34.708 (J. Felbermeyer).

A final category of concealed reuse is the incorporation of sculpture into 'statue walls' by late-antique and medieval builders. Unfortunately, this activity was generally successful in permanently concealing the original imagery. Either the walls remain intact, continuing to guard their secrets, or the recoveries are too fragmentary to interpret. Archaeological investigation or fortuitous rebuilding and renovation has, however, overcome these impediments at some sites, permitting Robert Coates-Stephens (2007) to describe a broad gamut of the iconographical types and chronological periods involved, including pagan idols, private portraits and architectural elements extending from the Hellenistic period to the fourth century. ${ }^{33}$ To the extent that these fragments represent bits of free-standing statuary, the Christian absence is unsurprising; very few such sculptures were produced. But sarcophagi were also used as raw material for construction. Their bulk was an inconvenience but not an insurmountable obstacle, as they could be broken to bits just like statues and buildings. The lack of identifiably Christian imagery in disaggregated construction is, therefore, not highly probative but at least consistent with a pro-Christian bias in destructive reuse.

\section{CONCLUSION}

The statistics are imprecise and incomplete, but the essential finding is robust: there are far fewer fourth-century Roman sarcophagi without Christian imagery

33 See also Avagnina, Garibaldi and Salterini 1976-7; Bertelli, Guiglia Guidobaldi and Rovigatti Spagnoletti, 1976-7; Greenhalgh, 1989: 145-59; Coates-Stephens, 2001. 
than the pagan presence would suggest. This deficit cannot be explained away by errors of classification, gaps in cataloguing or anomalies in dating. A parting of the commemorative ways between Christians and non-Christians would explain the numbers, but neither literary nor material evidence implies any revolution in late pagan attitudes that would account for such a division.

The shortfall in sarcophagi without explicit Christian iconography is best attributed to a difference in survival rates. Several factors could have led to asymmetric preservation. Some Christian sarcophagi may have benefited from their deposition in Roman churches, church annexes or adjacent cemeteries, although archaeological data in this regard are severely limited. ${ }^{34}$ Selective iconoclasm was not likely a major ingredient. Pagan sarcophagi were often appropriated by later Christians, and neutral or secular themes would be less susceptible to physical attacks; yet, hatred or simply disrespect of images not meriting Christian veneration probably had some impact.

A tendency to conserve holy images, especially pictures of Christ, was probably the most important factor. At least some Christians must have hesitated to destroy them, whether motivated by pious admiration or superstitious fear. The preservative effect was evidently insufficient to prevent the wholesale loss of early Christian sarcophagi, but it did provide a comparative advantage. Corroboration of this intuition appears in certain patterns of reuse, in particular in the known instances of sarcophagi reversed or inverted in the Middle Ages. The instances are not many, but they do support the view that Christian and non-Christian imagery did not always receive the same treatment.

The pagan sarcophagus deficit is not mere statistical noise in the general swirl of destruction that eliminated tens of thousands of monuments. Nor, however, does it demand a vigorous or universal pattern of Christian bias; several hundred individual choices made over a millennium following the end of Roman production would suffice. The fourth-century pagan sarcophagus gap may therefore be regarded as an archaeological illusion arising from the cumulative effect of historical attitudes and behaviour.

Address for correspondence:

Dr Robert Couzin

64 Admiral Road, Toronto, Ontario M5R 2L5, Canada

robert.couzin@alum.utoronto.ca

34 On the placement of Christian sarcophagi in fourth-century Rome, see Dresken-Weiland, 2003: 98-147. Her catalogue, however, lists only 232 find-spots in Rome and Latium, many for pagan sarcophagi, of which 80 are in churches and 31 in catacombs $(295-345,357-94)$. These are very small numbers compared with the known corpus. On the lamentable state of the archaeological evidence of Roman burial, including destruction within church precincts, see Christie, 2006: 153-4. 


\section{APPENDIX}

This Appendix provides additional information regarding the construction of Charts 1,2 and 3.

\section{Demography: Chart 1}

Chart 1 presents the following data, based on Couzin (2014):

\begin{tabular}{lcc}
\hline Years & Total & Pagan \\
\hline $275-325$ & 39,056 & 32,856 \\
$325-75$ & 26,806 & 17,093 \\
$375-425$ & 16,422 & 4,899 \\
\hline
\end{tabular}

The methodology may be summarized as follows:

1. The cost of a sarcophagus was calculated by multiplying the quantity of material (based on average size) and days of labour (mainly carving) by unit costs derived from Diocletian's Prices Edict of 301, a methodology similar to DeLaine (1997). The results compare favourably to spotty epigraphic evidence. The analysis was performed for Christian sarcophagi, but no adjustment should be required for neutral or pagan monuments.

2. The number of individuals wealthy enough to purchase a sarcophagus was derived from population estimates and income distribution models. The urban population as a whole was considered to have declined from 900,000 in AD 250 to 600,000 by 400 (see, in particular, Purcell, 1999). Studies of income in ancient Rome and its distribution (Scheidel and Friesen, 2009; Milanovic, 2010) were extrapolated taking into account fourth-century conditions, in particular a decline in per capita income and increase in inequality (Hopkins, 2002: 207; Jongman, 2006: 247; Milanovic, 2010: 19). Having regard to the levels of income and the cost of a sarcophagus, the number of sufficiently well-to-do Romans was estimated to have fallen by two-thirds from AD 250 to 400, from over 60,000 to under 20,000.

3. The Christian and non-Christian components were then disaggregated. The literature on rates of Roman Christianization is voluminous (see, in particular, Stark, 1996; Hopkins, 1998). A complicating feature is religious fluidity (Kahlos, 2007; Cameron, 2011a: 176-7; Jones, 2012); however, any uncertainty at the margins would not likely affect the general conclusion. The Christian population of Rome was estimated at 5 per cent in 250, rising to 75 per cent by 400 . The rate of Christianization of upper income groups is controversial (Haehling, 1978; Barnes, 1995; Mathisen, 2002; Salzman, 2002; Cameron, 2011a: 173-205). A judgment was made to take some delay into account; the percentage of well-to-do Christians was treated as somewhat lower at first, rising to equality with Christian numbers in general by 400 .

4. To facilitate comparison with sarcophagus data, these population figures were converted into annual anticipated deaths by applying an average mortality rate (Scheidel, 1999; Woods, 2007). Since the great majority of preserved sarcophagi were made for adults, the numbers were halved as a rough way to account for childhood mortality; this affects the absolute numbers of the vertical scale, but not the substance of the chart. 
The data so determined were cumulated as quarter-century sums on a simple linear assumption; e.g. the number of deaths for the period $275-325$ is equal to 50 times the arithmetic average of annual deaths for that period.

\section{Sarcophagi: Chart 2}

Chart 2 presents the following data:

\begin{tabular}{lrr}
\hline Years & Pagan & Total \\
\hline $275-325$ & 1,329 & 1,691 \\
$325-75$ & 108 & 485 \\
$375-425$ & 13 & 187 \\
\hline
\end{tabular}

As noted in the text, Dresken-Weiland (2003: 64-5, table 8) tabulated pagan and Christian sarcophagi from published catalogues. In comparable format, her results were:

\begin{tabular}{lcc}
\hline Years & Pagan & Total \\
\hline $270-300$ & 788 & 859 \\
$300-30$ & 317 & 780 \\
$330-400$ & 12 & 337 \\
\hline
\end{tabular}

The Chart 2 data significantly increase Dresken-Weiland's ‘pagan' category. A net increase of about 60 sarcophagi is due to minor adjustments, both positive and negative, based on the author's review of the publications and the addition of the later-published ASR I.3. A much more important addition arises from the strict classification criteria for Christian attribution, as discussed in the text. The methodology was as follows:

1. The Christian sarcophagus corpus was initially based on the inventories prepared by Koch, ${ }^{1}$ adjusted mainly to exclude sarcophagi used outside Rome to preserve comparability with the demography analysis. ${ }^{2}$ The number of Christian sarcophagi was thereby estimated at just over 600. The comparable Repertorium number is almost 1,200, about 1,400 in Provoost (2011).

2. In order to err on the side of generosity towards the pagan numbers, Provoost's figures were used to identify an additional group of sarcophagi that could be regarded as potentially used by non-Christians, numbering about 750 . This group was divided amongst the three half-century periods from AD 275 to 425, based on a review of the dates assigned to the excluded pieces by the Repertorium (on which Provoost generally relies for dating).

3. Finally, the additional sarcophagi assigned to each period were allocated between the pagan and Christian categories by applying the pagan and Christian percentages otherwise applicable to each period, i.e. the percentages determined before making the addition. The result is to substantially increase the number of pagan sarcophagi, with a much smaller change in their percentage of the total.

1 Koch, 2000: 238-48 ('Pre-Constantinian'), 260-80 ('Constantinian'), 289-96 ('postConstantinian'), 312-31 ('Valentinian-Theodosian') and 336-9 ('after 400').

2 For statistical purposes, and as a matter of convenience, Rome includes Ostia. The results would not change materially if a narrower definition of the metropolis were used. 
4. One alternative would have been to allocate the excess 750 sarcophagi based on population percentages. This is over-generous to the pagans, as it assumes a greater participation in sarcophagus use with respect to the ambiguous and fragmentary monuments than is seen in the cases that can be verified. Nonetheless, this alternative provides a useful check. It shows a smaller but still clear deficit, as noted below in connection with Chart 3.

\section{Comparison: Chart 3}

This chart combines the data in Charts 1 and 2 .

The hatched column, labelled '\% pagan deaths', is a restatement of the values in the data table above for Chart 1, dividing the pagan by the total for each half-century period. The solid column, labelled '\% pagan sarcophagi', similarly restates the values in the data table above for Chart 2.

The same operation applying the alternative, more generous, method of allocating additional sarcophagi between pagans and Christians based on population percentages would raise the solid bar for the mid-century period from 22 per cent (as shown in Chart 3) to 38 per cent, still well below the population percentage of 64 per cent. For the final half-century, the figure of 7 per cent would rise to 11 per cent.

\section{REFERENCES}

\section{Abbreviations}

ASR I.3 Reinsberg, C. (2006) Die Sarkophage mit Darstellungen aus dem Menschenleben. Vita Romana. Berlin, Gebr. Mann.

ASR IV.4 Matz, F. (1968-75) Die dionysischen Sarkophage. Die Denkmäler 246-385. Berlin, Gebr. Mann.

ASR Bielefeld, D. (1997) Die stadtrömischen Eroten-Sarkophage-

V.2.2 Weinlese- und Ernteszenen. Berlin, Gebr. Mann.

ASR V.4 Kranz, P. (1984) Jahreszeiten-Sarkophage: Entwicklung und Ikonographie des Motivs der vier Jahreszeiten auf kaiserzeitlichen Sarkophagen und Sarkophagdeckeln. Berlin, Gebr. Mann.

ASR VI.1 Stroszeck, J. (1998) Die dekorativen römischen Sarkophage. Die Löwen-Sarkophage. Die Sarkophage mit Löwenköpfen, schreitenden Löwen und Löwenkampfgruppen. Berlin, Gebr. Mann.

ASR Kollwitz, J. and Herdejürgen, H. (1975) Die Sarkophage der westlichen

VIII.2 Gebiete des Imperium Romanum. Die ravennatischen Sarkophage. Berlin, Gebr. Mann.

ASR Sichtermann, H. (1992) Die mythologischen Sarkophage. Apollon, XII.2 Ares, Bellerophon, Daidalos, Endymion, Ganymed, Giganten, Grazien. Berlin, Gebr. Mann. 
C. Th. Codex Theodosianus. Theodosiani libri XVI cum constitutionibus Sirmondianis et Leges novellae ad Theodosianum pertinentes, 1905. Berlin, Weidmann.

CIL Corpus Inscriptionum Latinarum, 1862-. Berlin, De Gruyter.

LSA The Last Statues of Antiquity database. University of Oxford. http:// laststatues.classics.ox.ac.uk/

Rep. I Bovini, G. and Brandenburg, H. (1967) Repertorium der christlichantiken Sarkophage I. Rom und Ostia. Wiesbaden, F. Steiner.

Rep. II Dresken-Weiland, J. (1998) Repertorium der christlich-antiken Sarkophage II. Italien mit einem Nachtrag Rom und Ostia, Dalmatien, Museen der Welt. Mainz, Philipp von Zabern.

Rep. III Christern-Briesenick, B. (2003) Repertorium der christlich-antiken Sarkophage III. Frankreich, Algerien, Tunesien. Mainz, Philipp von Zabern.

\section{Secondary sources}

Agosti, G., Farinella, V., Gallo, D. and Tedeschi Crisanti, G. (1984) Visibilità e reimpiego: 'A Roma anche i morti e le loro urne camminano'. In B. Andreae and S. Settis (eds), Colloquio sul reimpiego dei sarcofagi romani nel medioevo: Pisa 5. - 12. September 1982: 155-70. Marburger Winckelmann-Programm 1983. Marburg, Verlag des Kunstgeschichtlichen Seminars Marburg/Lahn.

Andreae, B. and Jung, H. (1977) Vorläufige tabellarische Übersicht über die Zeitstellung und Werkstattzugehörigkeit von 250 römischen Prunksarkophagen des 3. Jhs. n. Chr. Archäologischer Anzeige 1977: 432-6.

Andreae, B. and Settis, S. (1984) (eds) Colloquio sul reimpiego dei sarcofagi romani nel medioevo: Pisa 5. - 12. September 1982. Marburger Winckelmann-Programm 1983. Marburg, Verlag des Kunstgeschichtlichen Seminars Marburg/Lahn.

Arias, P.E., Cristiani, E. and Gabba, E. (1977) Camposanto monumentale di Pisa. I: le antichità. Pisa, Pacini.

Avagnina, M., Garibaldi, V. and Salterini, C. (1976-7) Le strutture murarie degli edifici religiosi di Roma nel XII secolo. Rivista di Archeologia Cristiana 23-24: 173-256.

Baratta, G. (2008) Materiale per un catalogo preliminare di sarcofagi strigilati a mandorla centrale: un primo approccio ad un corpus. Annali della Facoltà di Lettere e Filosofia dell'Università di Macerata 39 (2006): 65-120.

Baratta, G. (2011) Il paradosso di Eutropos: sull'iconografia di ICUR VI, 17225. In I. Piso (ed.), Scripta Classica. Radu Ardevan Sexagenario Dedicata: 31-40. Cluj-Napoca, Mega Publishing House.

Barbavara di Gravellona, T. (2002) Visibilità effimera, visibilità negata: sarcofagi romani reimpiegati e obliterati nel medioevo. In W. Cupperi (ed.), Senso delle rovine e riuso dell'antico. Annali della Scuola Normale Superiore di Pisa, classe lettere e filosofia, Serie 4. Quaderni 14: 199-217. Pisa, Scuola Normale Superiore.

Barnes, T. (1995) Statistics and the conversion of the Roman aristocracy. Journal of Roman Studies 85: 135-47.

Bartman, E. (1993) Carving the Badminton Sarcophagus. Metropolitan Museum Journal 28: 57-75.

Bejor, G. (1984) Il reimpiego di sarcofagi antichi nell'Italia Langobarda. In B. Andreae and S. Settis (eds), Colloquio sul reimpiego dei sarcofagi romani nel medioevo: Pisa 5. - 12. September 1982: 
93-102. Marburger Winckelmann-Programm 1983. Marburg, Verlag des Kunstgeschichtlichen Seminars Marburg/Lahn.

Bertelli, G., Guiglia Guidobaldi, A. and Rovigatti Spagnoletti, P. (1976-7) Le strutture murarie degli edifici religiosi di Roma dal VI al IX secolo. Rivista di Archeologia Cristiana 23-24: 95-172.

Birk, S. (2013) Depicting the Dead: Self-representation and Commemoration on Roman Sarcophagi with Portraits. Aarhus, Aarhus University Press.

Bovini, G. (1946-8) Le scene della 'dextrarum iunctio' nell'arte cristiana. Bullettino della Commissione Archeologica Comunale di Roma 72: 103-17.

Brandenburg, H. (2002) Das Ende der antiken Sarkophagkunst in Rom: pagane und christliche Sarkophage im 4. Jahrhundert. In G. Koch (ed.), Akten des Symposiums "frühchristliche Sarkophage”: Marburg, 30.6.-4.7: 19-39. Mainz on Rhine, Philipp von Zabern.

Brandenburg, H. (2004) Osservazioni sulla fine della produzione e dell'uso dei sarcofagi a rilievo nella tarda antichità nonché sulla loro decorazione. In F. Bisconti and H. Brandenburg (eds), Sarcofagi tardoantichi, paleocristiani e altomedievali: 1-34. Vatican City, Pontificio Istituto di Archeologia Cristiana.

Bridges, S. and Ward Perkins, J. (1956) Fourteenth-century Neapolitan military effigies, with notes on the families represented. Papers of the British School at Rome 24: 158-73.

Brilliant, R. and Kinney, D. (2011) Reuse Value: Spolia and Appropriation in Art and Architecture from Constantine to Sherrie Levine. Farnham, Ashgate.

Caldelli, M.L. (1997) Nota su $\mathrm{D}$ (is) M(anibus) et $\mathrm{D}$ (is) $\mathrm{M}$ (anibus) $\mathrm{S}$ (acrum) nelle iscrizioni cristiane di Roma. In I. Di Stefano Manzella (ed.), Le iscrizioni dei cristiani in Vaticano: materiali e contributi scientifici per una mostra epigrafica: 185-7. Vatican City, Monumenti, Musei e Gallerie Pontificie.

Cameron, A. (2011a) The Last Pagans of Rome. New York, Oxford University Press.

Cameron, A. (2011b) Antiquus Error / novus error: the HA, Nichomachus Flavianus, and the 'pagan resistance'. [Review of Stéphane Ratti, Antiquus Error: Les ultimes feux de la résistance païenne.] Journal of Roman Archaeology 24: 835-46.

Cameron, A. (2016) Were pagans afraid to speak their minds in a Christian world? The correspondence of Symmachus. In M.R. Salzman, M. Sághy and R. Lizzi Testa (eds), Pagans and Christians in Late Antique Rome: Conflict, Competition, and Coexistence in the Fourth Century: 64-111. New York, Cambridge University Press.

Cantino Wataghin, G. (2011) I primi cristiani, tra imagines, historiae e pictura: spunti di riflessione. Antiquité Tardive 19: 13-33.

Carletti, C. (2004) Dies mortis-depositio: un modulo 'profano' nell'epigrafia tardoantica. Vetera Christianorum 41: 21-48.

Carletti, C. (2015) No. 4414, ICVR VI, 17225. In Epigraphic Database Bari, Università degli Studi di Bari 'Aldo Moro', http://www.edb.uniba.it/.

Casimiro Romano, P.F. (1736). Memorie istoriche della Chiesa e Convento di S. Maria in Aracoeli di Roma. Rome, Rocco Bernabò.

Cattalini, D. (1984) 'Cuerpos santos' e sarcofagi romani in Sardegna. In B. Andreae and S. Settis (eds), Colloquio sul reimpiego dei sarcofagi romani nel medioevo: Pisa 5. - 12. September 1982: 217-27. Marburger Winckelmann-Programm 1983. Marburg, Verlag des Kunstgeschichtlichen Seminars Marburg/Lahn.

Chenault, R. (2012) Statues of senators in the Forum of Trajan and the Roman Forum in late antiquity. Journal of Roman Studies 102: 103-32.

Christie, N. (2006) From Constantine to Charlemagne: An Archaeology of Italy, AD 300-800. Aldershot, Ashgate.

Coates-Stephens, R. (2001) Muri dei bassi secoli in Rome: observations on the re-use of statuary in walls found on the Esquiline and Caelian after 1870. Journal of Roman Archaeology 14: 217-38. 
Coates-Stephens, R. (2007) The reuse of ancient statuary in late antique Rome. In F.A. Bauer and C. Witschel (eds), Statuen in der Spätantike: 171-87. Wiesbaden, Reichert.

Couzin, R. (2014) The Christian sarcophagus population of Rome. Journal of Roman Archaeology 27: 275-303.

Couzin, R. (2017) Syncretism and segregation in early Christian art. Studies in Iconography 38: $18-54$.

Daehner, J.M. and Lapatin, K. (2015) Reframing Hellenistic bronze sculpture. In J.M. Daehner and K. Lapatin (eds), Power and Pathos: Bronze Sculpture of the Hellenistic World (exh. cat.): 20-33. Los Angeles, Getty Publications.

DeLaine, J. (1997) The Baths of Caracalla: A Study in the Design, Construction, and Economics of Large-Scale Building Projects in Imperial Rome. Portsmouth (RI), Journal of Roman Archaeology.

De Rossi, G.B. (1877) La Roma sotterranea cristiana III. Rome, Salviucci.

De Santis, P. (2013) Memoria e commemorazione funeraria nelle lastre incise di committenza cristiana. In F. Bisconti and M. Braconi (eds), Incisioni figurate della tarda antichità: Atti del Convegno di Studi, Roma Palazzo Massimo, 22-23 marzo 2012: 381-404. Vatican City, Pontificio Istituto di Archeologia Cristiana.

Donati, F. (1996) Sarcofagi per corpi santi e la 'politica museale' di Lasinio nel lato est del Camposanto di Pisa. Bollettino Storico Pisano 65: 87-114.

Dresken-Weiland, J. (2003) Sarkophagbestattungen des 4.-6. Jahrhunderts im Westen des römischen Reiches. Rome, Herder.

Elsner, J. (2003) Archaeologies and agendas: reflections on late ancient Jewish art and early Christian art. Journal of Roman Studies 93: 114-28.

Elsner, J. (2011) Introduction. In J. Elsner and J. Huskinson (eds), Life, Death and Representation: Some New Work on Roman Sarcophagi: 1-20. Berlin, De Gruyter.

Elsner, J. (2012) Decorative imperatives between concealment and display: the form of sarcophagi. Res 61/62: 178-85.

Esch, A. (1969) Spolien. Zur Wiederverwendung antiker Baustücke und Skulpturen im mittelalterlichen Italien. Archiv für Kulturgeschichte 51: 1-64.

Fant, J.C. (2008) Quarrying and stoneworking. In J.P. Oleson (ed.), The Oxford Handbook of Engineering and Technology in the Classical World: 121-35. Oxford, Oxford University Press.

Gabrielli, G.M. (1961) I sarcofagi paleocristiani e altomedioevali delle Marche. Ravenna, Dante.

Gardner, J. (1992) The Tomb and the Tiara: Curial Tomb Sculpture in Rome and Avignon in the Later Middle Ages. New York, Oxford University Press.

Garms, J., Juffinger, R. and Ward-Perkins, B. (1981) (eds) Die mittelalterlichen Grabmäler in Rom und Latium vom 13. bis zum 15. Jahrhundert, 1: Die Grabplatten und Tafeln. Rome/Vienna, Österreichischen Akademie der Wissenschaften.

Garms, J., Sommerlechner, A. and Telesko, W. (1994) (eds) Die mittelalterlichen Grabmäler in Rom und Latium vom 13. bis zum 15. Jahrhundert, 2: Die Monumentalgräber. Rome/Vienna, Österreichischen Akademie der Wissenschaften.

Gori, F. (2005) Lastra sepolcrale di Eutropos. In G. De Marinis (ed.), Arte romana nei musei delle Marche: 281-2, cat. 149. Rome, Istituto Poligrafico e Zecca dello Stato.

Gori, G. (2007) Lastra sepolcrale di Eutropos. In F. Bisconti and G. Gentili (eds), La rivoluzione dell'immagine: arte paleocristiana tra Roma e Bisanzio: 176-7, cat. 38. Turin, Silvana.

Greenhalgh, M. (1989) The Survival of Roman Antiquities in the Middle Ages. London, Duckworth.

Greenhalgh, M. (2009) Marble Past, Monumental Present: Building with Antiquities in the Mediaeval Mediterranean. Leiden / Boston (MA), Brill. 
Haehling, R. von (1978) Die Religionszugehörigkeit der hohen Amtsträger des römischen Reiches seit Constantins I Alleinherrschaft bis zum Ende der Theodosianischen Dynastie, 324-450 bzw. 455 n. Chr. Bonn, R. Habelt.

Hijmans, S. (2000) Language, metaphor, and the semiotics of Roman art: some thoughts on reading the mosaics of Mausoleum $\mathrm{M}$ in the Vatican necropolis. BABESCH (Bulletin Antieke Beschaving) 75: 147-64.

Hopkins, K. (1998) Christian number and its implications. Journal of Early Christian Studies 6: 185-226.

Hopkins, K. (2002) Rome, taxes, rents and trade. In W. Scheidel and S. von Reden (eds), The Ancient Economy: 190-230. Edinburgh, Edinburgh University Press.

Huskinson, J. (2011) Habent sua fata: writing life histories of Roman sarcophagi. In J. Elsner and J. Huskinson (eds), Life, Death and Representation: Some New Work on Roman Sarcophagi: 55-82. Berlin, De Gruyter.

Huskinson, J. (2015) Roman Strigillated Sarcophagi: Art and Social History. Oxford, Oxford University Press.

Jones, C.P. (2012) The fuzziness of 'paganism'. Common Knowledge 18: 249-54.

Jones, C.P. (2014) Between Pagan and Christian. Cambridge (MA), Harvard University Press.

Jongman, W. (2006) The rise and fall of the Roman economy: population, rents and entitlement. In P. Fibiger Bang, M. Ikeguchi and H.G. Ziche (eds), Ancient Economies, Modern Methodologies: Archaeology, Comparative History, Models and Institutions: 237-54. Bari, Edipuglia.

Kahlos, M. (2002) Vettius Agorius Praetextatus - A Senatorial Life in Between. Acta Instituti Romani Finlandiae no. 26. Rome, Institutum Romanum Finlandiae.

Kahlos, M. (2007) Debate and Dialogue: Christian and Pagan Cultures c. 360-430. Aldershot, Ashgate.

Kinney, D. (1997) Spolia. Damnatio and renovatio memoriae. Memoirs of the American Academy in Rome 42: 117-48.

Klauser, T. (1958-67) Studien zur Entstehungsgeschichte der christlichen Kunst I-IX. Jabrbuch für Antike und Christentum 1: 20-51; 2: 115-45; 3: 112-33; 4: 128-45; 5: 113-24; 6: 71-100; 7: 67-76; 8-9: 126-70; 10: 82-120.

Koch, G. (2000) Frühchristliche Sarkophage. Munich, C.H. Beck.

Koch, G. (2002) Jüdische Sarkophage der Kaiserzeit und der Spätantike. In L.V. Rutgers (ed.), What Athens Has to Do with Jerusalem: Essays on Classical, Jewish, and Early Christian Art and Archaeology in Honor of Gideon Foerster: 189-210. Leuven, Peeters.

Koch, G. and Sichtermann, H. (1982) Römische Sarkophage. Munich, C.H. Beck.

Koortbojian, M. (2013) The mythology of everyday life. In M. Galinier and F. Baratte (eds), Iconographie funéraire romaine et société: Corpus antique, approches nouvelles?: 147-69. Perpignan, Presses Universitaires de Perpignan.

Kraemer, R.S. (1991) Jewish tuna and Christian fish: identifying religious affiliation in epigraphic sources. Harvard Theological Review 84: 141-63.

Kristensen, T.M. and Stirling, L. (2016) Introduction. In T.M. Kristensen and L. Stirling (eds), The Afterlife of Greek and Roman Sculpture: Late Antique Responses and Practices: 3-24. Ann Arbor, University of Michigan Press.

L'Orange, H.P. and Gerkan, A. von (1939) Der spätantike Bildschmuck des Konstantinsbogens. Berlin, De Gruyter.

Luschi, L. (1984) Viterbo e i centri abbaziale di Lazio: primi risultati di un indagine sui sarcofagi romani reimpiegati. In B. Andreae and S. Settis (eds), Colloquio sul reimpiego dei sarcofagi romani nel medioevo: Pisa 5. - 12. September 1982: 171-85. Marburger WinckelmannProgramm 1983. Marburg, Verlag des Kunstgeschichtlichen Seminars Marburg/Lahn.

MacMullen, R. (1984) Christianizing the Roman Empire (A.D. 100-400). New Haven/London, Yale University Press. 
Marcotti, G. (1879) Vincigliata. Florence, G. Barbèra.

Mathisen, R.W. (2002) The Christianization of the Late Roman senatorial order: circumstances and scholarship. International Journal of the Classical Tradition 9: 257-78.

Matthews, J. (2009) Four funerals and a wedding: this world and the next in fourth-century Rome. In P. Rousseau and M. Papoutsakis (eds), Transformations of Late Antiquity: Essays for Peter Brown: 129-46. Farnham / Burlington (VT), Ashgate.

Milanovic, B. (2010) Income level and income inequality in the Euro-Mediterranean region: from the Principate to the Islamic conquest. Paper presented at the Angus Maddison Memorial Conference, Amsterdam, 6-7 November 2010. http://www.ggdc.net/maddison/maddison conference2010/maddison_conference_nov2010_milanovic.pdf.

Noè, V. (2000) Le tombe e i monumenti funebri dei papi nella Basilica di San Pietro in Vaticano. Modena, F.C. Panini.

North, J.A. (2005) Pagans, polytheists and the pendulum. In W.V. Harris (ed.), The Spread of Christianity in the First Four Centuries: Essays in Explanation: 125-43. Leiden, Brill.

Paribeni, R. (1909) Incrementi del Museo Nazionale Romano. Bollettino d'Arte 3: 295-306.

Pesce, G. (1957) Sarcofagi romani di Sardegna. Rome, Bretschneider.

Porcu Gaias, M. (1996) Sassari. Storia architettonica e urbanistica dalle origine al '600. Nuoro, Ilisso.

Provoost, A. (2004) Pastor or Pastor Bonus?: The interpretation and evolution of pastoral scenes in the late antiquity. Church History and Religious Culture 84: 1-36.

Provoost, A. (2011) De vroegchristelijke funeraire beeldtaal: Met chronologisch repertorium van de catacombenschilderingen in Rome en van de vroegchristelijke sarcofagen. Leuven, Onderzoekseenheid Archeologie K.U. Leuven.

Prusac, M. (2016) From Face to Face: Recarving of Roman Portraits and the Late-antique Portrait Arts (second edition). Leiden / Boston (MA), Brill.

Purcell, N. (1999) The populace of Rome in late antiquity. In W.V. Harris (ed.), The Transformations of Vrbs Roma in Late Antiquity: 135-61. Portsmouth (RI), Journal of Roman Archaeology.

Ratti, S. (2010) Antiquus Error: Les ultimes feux de la résistance païenne: Scripta varia angmenté de cinq études inédites. Turnhout, Brepols.

Ratti, S. (2012) Polémiques entre païens et chrétiens. Paris, Les Belles Lettres.

Rutgers, L.V. (2006) Reflections on the demography of the Jewish community of ancient Rome. In M. Ghilardi, C.J. Goddard and P. Porena (eds), Les cités de l'Italie tardo-antique, IVe-VIe siècle: Institutions, économie, société, culture et religion: 345-58. Rome, École Française de Rome.

Rutgers, L.V. (2013) Cemeteries and catacombs. In P. Erdkamp (ed.), The Cambridge Companion to Ancient Rome: 497-521. Cambridge, Cambridge University Press.

Salzman, M.R. (2002) The Making of a Christian Aristocracy: Social and Religious Change in the Western Roman Empire. Cambridge (MA), Harvard University Press.

Scheidel, W. (1999) Emperors, aristocrats and the Grim Reaper: towards a demographic profile of the Roman elite. Classical Quarterly 49: 254-81.

Scheidel, W. and Friesen, S.J. (2009) The size of the economy and the distribution of income in the Roman Empire. Journal of Roman Studies 99: 60-91.

Settis, S. (2004) Riusare l'antico, mutare il presente. In G. Borghini, P. Callegari and L. Nista (eds), Roma: Il riuso dell'antico: fotografie tra XIX e XX secolo: Roma, Olearie, Terme di Diocleziano, 25 giugno - 15 ottobre 2004: 11-18. Bologna: Bononia University Press.

Stark, R. (1996) The Rise of Christianity: A Sociologist Reconsiders History. Princeton, Princeton University Press.

Stewart, A. (1990) Greek Sculpture: An Exploration. New Haven/London, Yale University Press.

Stutzinger, D. (1982) Die frühchristlichen Sarkophagreliefs aus Rom: Untersuchungen zur Formveränderung im 4. Jahrhundert $n$. Chr. Bonn, R. Habelt. 
Varner, E.R. (2004) Mutilation and Transformation: Damnatio Memoriae and Roman Imperial Portraiture. Leiden, Brill.

Veyne, P. (2005) L'empire gréco-romain. Paris, Seuil.

Wiegartz, V. (2004) Antike Bildwerke im Urteil mittelalterlicher Zeitgenossen. Weimar, VDG.

Wilpert, J. (1929-32) I sarcofagi cristiani antichi. Rome, Pontificio Istituto di Archeologia Christiana.

Woods, R. (2007) Ancient and early modern mortality: experience and understanding. Economic History Review 60: 373-99.

Wrede, H. (2001) Senatorische Sarkophage Roms: Der Beitrag des Senatorenstandes zur römischen Kunst der hohen und späten Kaiserzeit. Monumenta Artis Romanae XXIX. Mainz, Philipp von Zabern.

Zalum, M. (2000) Tomb (late antique sarcophagus reworked in the late-14th century) of Urban VI. In A. Pinelli (ed.), The Basilica of St Peter in the Vatican II, trans. U. Creagh et al. Mirabilia Italiae 10: 894-5, no. 1765. Modena, F.C. Panini.

Zanker, P. (2005) Ikonographie und Mentalität. Zur Veränderung mythologischer Bildthemen auf den kaiserzeitlichen Sarkophagen aus der Stadt Rom. In R. Neudecker and P. Zanker (eds), Lebenswelten: Bilder und Räume in der römischen Stadt der Kaiserzeit: Symposium am 24. und 25. Januar 2002 zum Abschluss des von der Gerda Henkel Stiftung geförderten Forschungsprogramms ,Stadtkultur in der römischen Kaiserzeit': 243-51. Wiesbaden, Ludwig Reichert.

Zanker, P. and Ewald, B.C. (2012) Living with Myths: The Imagery of Roman Sarcophagi, trans. J. Slater. Oxford: Oxford University Press. 